\title{
Orchestration of Neuronal Differentiation and Progenitor Pool Expansion in the Developing Cortex by SoxC Genes
}

\author{
Chao Chen, ${ }^{1}$ Garrett A. Lee, ${ }^{1}$ Ariel Pourmorady, ${ }^{1}$ Elisabeth Sock, ${ }^{2}$ and ${ }^{-}$Maria J. Donoghue ${ }^{1}$ \\ ${ }^{1}$ Department of Biology, Georgetown University, Washington, DC 20057, and ${ }^{2}$ Institute of Biochemistry, Friedrich-Alexander University Erlangen- \\ Nuernberg, 91054 Erlangen, Germany
}

\begin{abstract}
As the cerebral cortex forms, specialized molecular cascades direct the expansion of progenitor pools, the differentiation of neurons, or the maturation of discrete neuronal subtypes, together ensuring that the correct amounts and classes of neurons are generated. In several neural systems, the SoxC transcriptional regulators, particularly Sox 11 and Sox4, have been characterized as functioning exclusively and redundantly in promoting neuronal differentiation. Using the mouse cerebral cortex as a model, Sox11 and Sox4 were examined in the formation of the most complex part of the mammalian brain. Anticipated prodifferentiation roles were observed. Distinct expression patterns and mutant phenotypes, however, reveal that Sox 11 and Sox4 are not redundant in the cortex, but rather act in overlapping and discrete populations of neurons. In particular, Sox11 acts in early-born neurons; binding to its partner protein, Neurogenin1, leads to selective targeting and transactivation of a downstream gene, NeuroD1. In addition to neuronal expression, Sox 4 was unexpectedly expressed in intermediate progenitor cells, the transit amplifying cell of the cerebral cortex. Sox 4 mutant analyses reveal a requirement for Sox4 in IPC specification and maintenance. In intermediate progenitors, Sox4 partners with the proneural gene Neurogenin2 to activate Tbrain2 and then with Tbrain2 to maintain this cell fate. This work reveals an intricately structured molecular architecture for SoxC molecules, with Sox11 acting in a select set of cortical neurons and Sox 4 playing an unanticipated role in designating secondary progenitors.
\end{abstract}

Key words: intermediate progenitor cell; neuronal differentiation; SoxC

\section{Introduction}

The cerebral cortex consists of vast quantities of neurons and glia connected in stereotyped manners to produce a circuitry capable of generating predictable yet tunable responses (Sidman, 1982; Kriegstein, 2005). How are the cells that underlie this complexity generated during corticogenesis? Within the neocortex, there is initial emphasis on the production of cells as dividing cells create daughter cells that are also mitotically active. Regulated cell division ensures that enough cells are created to populate the mature cortex (Takahashi et al., 1994; Kriegstein et al., 2006). Excitatory neurons are produced from cortical germinal zones (Rakic, 1972; Noctor et al., 2004) and inhibitory neurons are generated in subcortical ganglionic eminences (Anderson et al., 1997). In matu-

\footnotetext{
Received April 29, 2015; revised June 8, 2015; accepted June 10, 2015

Author contributions: C.C. and M.J.D. designed research; C.C., G.A.L., and A.P. performed research; E.S. contributed unpublished reagents/analytic tools; C.C. and M.J.D. analyzed data; C.C., G.A.L., E.S., and M.J.D. wrote the paper.

This work was supported by institutional funding from Georgetown University. G.A.L. and A.P. were supported by the Howard Hughs Medical Institute University (Grant 52006925). We thank Veronique Lefebvre for Sox $4^{\mathrm{fl} / \mathrm{fl}}$ and Sox $11^{\mathrm{f} / \mathrm{fl}}$ mice; Robert Hevner, Jane Johnson, and David Anderson for antisera; Qiang Lu, Takaki Miyata, Lori Sussel, Jane Johnson, Pasko Rakic, and Veronique Lefebvre for providing plasmids; members of the Donoghue laboratory, particularly Carrie Leonard, Lauren Orefice, and Denver Burton, for discussion and suggestions; the Silva research group for important insights into Sox biology; and Elena Silva, Tom Coate, Jeff Huang, and members of the Neurobiology groups on the fourth floor of Regents Hall for discussions.

The authors declare no competing financial interests.

Correspondence should be addressed to Maria J. Donoghue, Department of Biology, Georgetown University, 37th and OSt. NW, Washington, DC 20057. E-mail: mjv23@georgetown.edu.

DOI:10.1523/JNEUROSCI.1663-15.2015

Copyright $\odot 2015$ the authors $\quad 0270-6474 / 15 / 3510629-14 \$ 15.00 / 0$
}

rity, there is limited innate capacity to generate new neurons in the cerebral cortex and embryonic proliferative zones are vestigial (Altman and Bayer, 1990).

The developing cerebral wall is functionally segregated, with dividing cells near the ventricles and differentiated populations located more superficially (Fig. 1A). The majority of proliferation occurs in the ventricular zone (VZ) as morphologically simple apical progenitors divide. An additional group of mitotically active cells exist in the adjacent subventricular zone (SVZ) and represents a developmental puzzle (Goldman, 1995; Haydar et al., 2000; Englund et al., 2005). Originally considered the proliferative compartment for glial cells (Luskin, 1998; Qian et al., 2000; Costa et al., 2009), several studies suggest that the SVZ is a germinal compartment for upper layer neurons (Tarabykin et al., 2001; Brazel et al., 2003; Zimmer et al., 2004; Wu et al., 2005; Zecevic et al., 2005), whereas more recent data reveal that neurons of all layers may be derived from the SVZ (Kowalczyk et al., 2009). Gene expression shifts as apical progenitors of the VZ are converted into basal progenitors of the SVZ (Tarabykin et al., 2001; Englund et al., 2005; Britz et al., 2006; Ochiai et al., 2009; Sessa et al., 2010). Compared with their VZ counterparts, dividing cells within the SVZ, intermediate progenitor cells (IPCs), have more complex morphology but limited mitotic potential (Noctor et al., 2002; Miyata et al., 2004; Noctor et al., 2004; Noctor et al., 2008). A compelling hypothesis is that some cellular guidance is imbued as IPCs undergo a final division in the novel environment of the SVZ (Noctor et al., 2004; Martínez-Cerdeño 
A
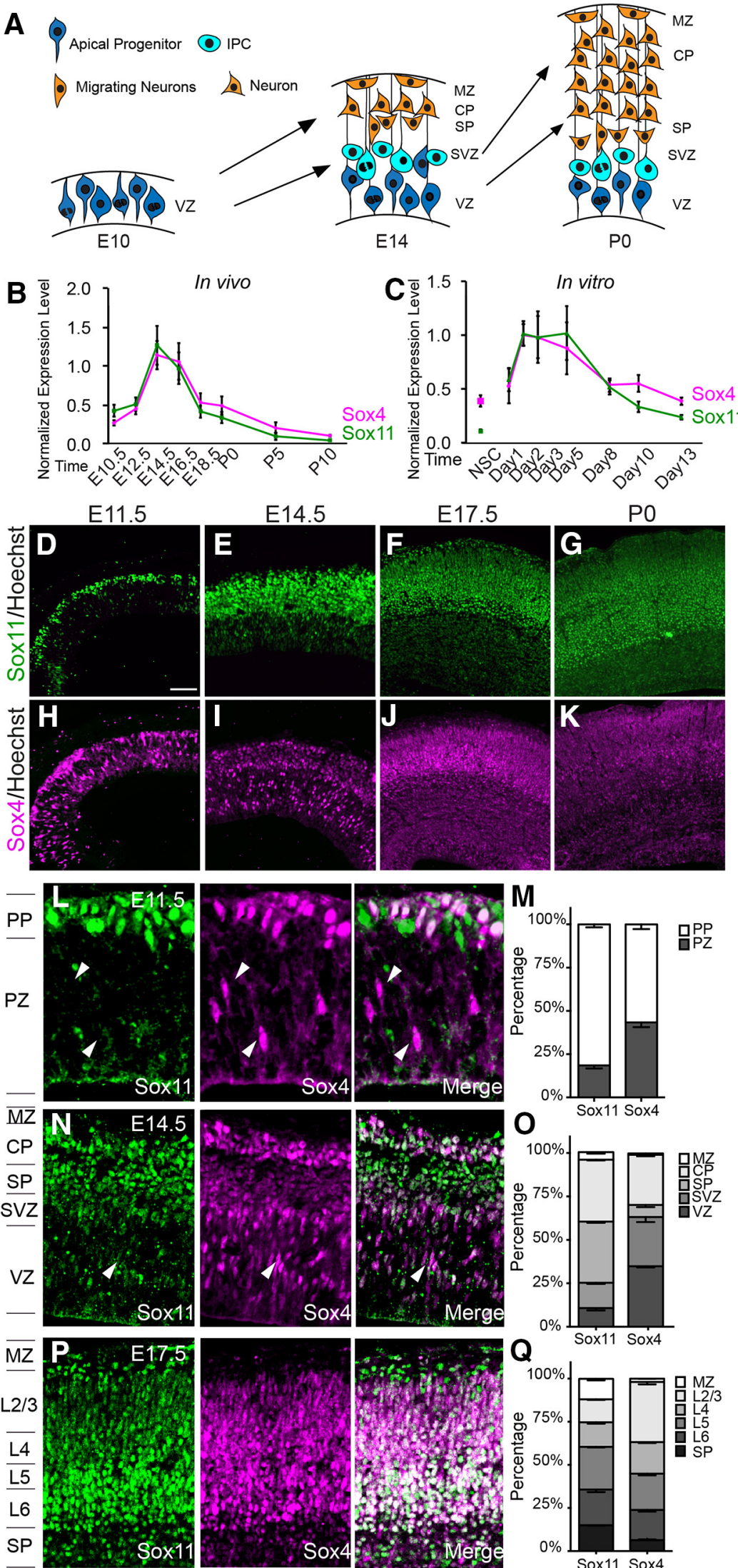

Q

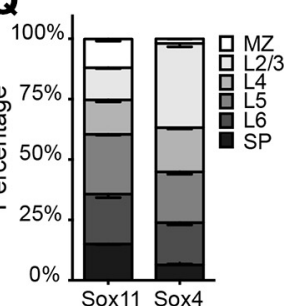

Figure 1. Sox11 and Sox4 are dynamically expressed during corticogenesis in overlapping and discrete cellular populations. $\boldsymbol{A}$, Schematic of corticogenesis with apical progenitors in the VZ (bright blue), IPCs in the SVZ (lighter blue), and neurons in the PP, SP MZ, and CP (red). $\boldsymbol{B}, \boldsymbol{C}$, Profiles of Sox 11 (green) and Sox4 (magenta) levels in cortical development $(\boldsymbol{B})$ and in cortical cultures $(\boldsymbol{C})$ obtained using qRT-PCR and normalized to U6 levels. $\boldsymbol{D}-\boldsymbol{K}$, Expression of Sox11 (D-G) and Sox4 $(\boldsymbol{H}-\boldsymbol{K})$ in mouse cerebral cortex at

et al., 2006; Noctor et al., 2007a,b, 2008; Javaherian and Kriegstein, 2009; Tyler et al., 2015).

During development, stereotyped processes transition mitotically active cells into neurons. Initially, proneural genes, such as the Neurogenins, are activated that promote cascades of other genes' expression, ultimately being responsible for neuronal shape and function (Ghysen and Dambly-Chaudiere, 1989; Kiefer et al., 2005; Wilkinson et al., 2013; Paul et al., 2014). Although general neurogenesis is well characterized, less is known about how neuronal diversity is generated and the value of IPC-based division (Arlotta et al., 2005; Molyneaux et al., 2007; Lai et al., 2008; Shim et al., 2012; Florio and Huttner, 2014).

In considering neurogenesis, members of the Sox family, a diverse set of transcriptional regulators that partner with other proteins to affect gene expression and specify cell fate, are important actors (Lefebvre et al., 2007; Guth and Wegner, 2008; Bergsland et al., 2011; Kamachi and Kondoh, 2013). In particular, members of the SoxC subfamily, consisting of Sox4, Sox11, and Sox12, are considered panneuronal and functionally identical (Cheung et al., 2000; Bergsland et al., 2006; Dy et al., 2008; Hoser et al., 2008; Potzner et al., 2010; Thein et al., 2010; Mu et al., 2012). Mice constitutively mutant for each SoxC family member have been generated: Sox $4^{-1-}$ mice have multiple defects and die as embryos at embryonic day 14 (E14) (Schilham et al., 1996), Sox $11^{-1-}$ mice display multiorgan alterations and die at birth (Sock et al., 2004), whereas Sox $12^{-/-}$mice appear normal (Hoser et al., 2008). Because preliminary results implicate Sox 4 and Sox11, but not Sox12, in cellular transitions in corticogenesis, Sox 4 and Sox 11 are the focus of this study.

\section{Materials and Methods}

Animal husbandry and tissue preparation. All animal use and care was in accordance with institutional, particularly Georgetown University's Institutional Animal Care and Use Com-

$\operatorname{E11.5}(\boldsymbol{D}, \boldsymbol{H}), \operatorname{E14.5}(\boldsymbol{E}, \boldsymbol{I}), \mathrm{E} 17.5(\boldsymbol{F}, \boldsymbol{J})$, and $\mathrm{PO}(\boldsymbol{G}, \boldsymbol{K})$ with white lines indicating the position of the ventricle and pial surface $(\boldsymbol{D}$, $\boldsymbol{H})$ or ventricle, lower $(\boldsymbol{P}$, and pial surface $(\boldsymbol{E}-\boldsymbol{K}) \cdot \boldsymbol{L}-\boldsymbol{Q}$, Expression $(\boldsymbol{L}, \boldsymbol{N}, \boldsymbol{P})$ and quantification of distribution $(\boldsymbol{M}, \mathbf{O}, \mathbf{Q})$ of Sox11 (green) and Sox4 (magenta) at E11.5 $(\boldsymbol{L}, \boldsymbol{M})$, E14.5 ( $N$, $\mathbf{0})$ and E17.5 $(\boldsymbol{P}, \mathbf{Q})$. Arrowheads indicate Sox $4^{+}$Sox $11^{--}$ cells in the apical cerebral wall (VZ and SVZ) and white cells reveal overlap of Sox 11 and Sox4. Scale bars: D, E, H, I, $64 \mu \mathrm{m}$; $\boldsymbol{F}, \mathbf{G}, \mathbf{J}, \boldsymbol{K}, 96 \mu \mathrm{m} ; \boldsymbol{L}, 24 \mu \mathrm{m} ; \boldsymbol{N}, \boldsymbol{P}, 40 \mu \mathrm{m}$. 
mittee (Protocol \#12-018-100035) and federal guidelines. For cortical tissue samples and cells, timed pregnant females, wild-type or mutant (described below) mice were either euthanized immediately or in utero electroporation was performed (see below) and then mice were euthanized. Brains or cerebral cortex of embryos, presumably equal amounts of both sexes, were dissected and either dissociated for cell culture or fixed, frozen, and sectioned for processing.

Quantitative RT-PCR. Total RNA was isolated from cerebral cortical tissue of E10.5, E12.5, E14.5, E16.5, E18.5, and postnatal day 0 (P0), P5, and P10 mice (in vivo) or cultures of neural stem cells (NSCs) and differentiated cortical cultures at days in vitro (DIV) 1, 2, 3, 5, 8, 10, and 13 using the Tri-Regent Kit (Sigma-Aldrich). cDNA was synthesized using the First-Strand cDNA Synthesis Kit (Invitrogen). Primers specific for Sox4, Sox11, and U6 (Sox4: forward: 5'ATGAACGCCTTTATGGTGTGGTCG-3', Reverse: 5' -TGAACGGAATCTTGTCGCTGTCCT-3'; Sox11: forward: 5'-TAAGGACCTGGATTCCT TCAGCGA-3', reverse: 5'-TCAATACGTGAACACCAGGTCGGA-3'; U6: forward: 5'-CTCGCTTCGGCAGCACA-3', reverse: 5'-AACGCTT CACGAATTTGCGT- $3^{\prime}$ ) were designed for use in quantitative real-time RTPCR (qRT-PCR). qRT-PCR was performed using the $2 \times$ SYBR Green PCR Master Mix (Bioline). Relative transcript levels were normalized to U6. All experiments were performed in duplicate and from at least three separate tissue or cell isolations.

Immunohistochemistry. Embryonic and postnatal brains were collected and fixed in $4 \%$ paraformaldehyde for $1-3 \mathrm{~h}$, cryoprotected in $30 \%$ sucrose overnight, and frozen in Tissue-Tek OCT Compound (Sakura Finetek). Then, $12 \mu \mathrm{m}$ sections were cut on a cryostat and mounted. Immunohistochemistry (IHC) was performed as described previously (Bultje et al., 2009) using the following primary antibodies: anti-Sox4 (1:1000; from the Sock laboratory; Hoser et al., 2008a), anti-Sox11 (1: 1500; from Sock laboratory; Hoser et al., 2008a), anti-BrdU (1:50; Becton Dickinson), anti-Ngn1 (1:1000; a gift from Jane Johnson, University of Texas Southwestern Medical Center), anti-Ngn2 (1:1000; R\&D Systems), anti-Tbr2 (1:500; Abcam), anti-Tbr1 (1:500; gift from Robert Hevner, University of Washington), anti-NeuroD (1:1000; Santa Cruz Biotechnology), anti-pPH3 (1:2000; Calbiochem), Tuj1 (1:1000; Covance), anti-Brn2 (1:500; Santa Cruz Biotechnology), anti-Ctip2 (1:500; Abcam), anti-Sox2 (1:300; R\&D Systems), anti-Caspase3 (1:1000; gift from Mark Burns, Georgetown University Medical Center), anti-Ki67 (1:500; Abcam), anti-Sox9 (1:1500; Abcam), and Hoechst (1:10,000; Life Technologies), together with species-appropriate Alexa Fluor secondary antibodies (Invitrogen).

Analysis of cell cycle. BrdU was injected intraperitoneally into wild-type E13.5 pregnant mice and embryos were harvested at E14.5. Brains were fixed in $4 \%$ paraformaldehyde for $2 \mathrm{~h}$, cryoprotected in 30\% sucrose overnight, frozen in Tissue-Tek OCT compound (Sakura Finetek), and cryosectioned in $12 \mu \mathrm{m}$ sections. The sections were mounted and stained for BrdU, Sox4, and Ki67 to investigate cell cycle status. Brdu ${ }^{+} \mathrm{Ki}^{-} 7^{-}$ cells had exited the cell cycle, whereas $\mathrm{Brdu}^{+} \mathrm{Ki} 67^{+}$were still mitotically active. Several fields of four samples were analyzed.

Mutant mouse analyses. Mice in which the Sox11 or Sox4 locus contained loxP recombination motifs were obtained from Veronique Lefebvre's laboratory (Cleveland Clinic). To inactivate Sox 11 or Sox4 in all cells of the developing forebrain, Sox $4^{\mathrm{fl} / \mathrm{fl}}$ or Sox $11^{\mathrm{fl} / \mathrm{fl}}$ mice were bred with Emx1-Cre animals, which express the Cre recombinase in all progenitor cells, thus producing mutant progenitors as well as all cells derived from mutant progenitors (Jackson Laboratories). Genotyping to distinguish wild-type, floxed, and deleted Sox $4 / 11$ alleles was performed as described previously (Jiang et al., 2013). Mice were maintained at the Georgetown University Animal facility, and experiments were performed in accordance with experimental protocols approved by local institutional animal care and use committees and federal guidelines. Four to six mice of each genotype were examined for all experiments.

In utero electroporation. Expression vectors for Sox 11 or Sox 4 GOF (gift from Veronique Lefebvre; Potzner et al., 2010) or shRNA constructs specific for Sox 11 or Sox 4 LOF (Sox4 shRNA sense strand sequence for ORF: 5'-GCGACAAGATTCCGTTCAT-3'; Sox11 shRNA sense strand sequence for ORF: 5'-GCAGGAAGATCATGGAGCA-3') and CMVeYFP and/or DCX-dsRed (gift from Qiang Lu) were delivered to the dorsal cortex via in utero electroporation as described previously (North et al., 2009). Briefly, E15.5 timed pregnant dams were anesthetized with $100 \mathrm{mg} / \mathrm{kg}$ ketamine and $10 \mathrm{mg} / \mathrm{kg}$ xylazine and the uterus was exposed by midline laparotomy. The lateral ventricle was injected with $1.5 \mu \mathrm{l}$ of a DNA solution containing $2 \mu \mathrm{g} / \mu \mathrm{l}$ plasmid and $0.02 \%$ fast-green in PBS. Seven-millimeter platinum tweezer-style electrodes were placed outside the uterus and across the embryonic head and four pulses of $33 \mathrm{~V}$ were applied at $40 \mathrm{~ms}$ intervals using a BTX square wave electroporator. The uterus was then placed back into the abdomen, the peritoneal cavity was filled with warm sterile saline, and the abdominal muscle and then skin incisions were closed with sutures. At E16.5, the embryos were harvested and processed for IHC. Four to six mice for each condition were examined for all experiments.

Cortical cultures. To transfect cortical cells, ex utero transfection was performed as described for in utero electroporation above except that embryos were removed from the uterus and amniotic sac and the cortex was dissected immediately after DNA was delivered (Clifford et al., 2014).

For differentiated cultures, following electroporation, the dorsal telencephalon was dissected in ice-cold HBSS supplemented with $0.5 \%$ D-glucose and $25 \mathrm{~mm}$ HEPES, the meninges were removed, and a single cell suspension was produced. For differentiated neuronal cultures, dissociated cells were plated at 500 cells $/ \mathrm{mm}^{2}$ under conditions that promote differentiation (Neurobasal media supplemented with $2 \%$ B27, $0.25 \%$ L-glutamine, $0.25 \%$ penicillin/streptomycin, $1 \mathrm{~mm}$ HEPES) onto coverslips coated with poly-D-lysine and laminin. Upon harvest, cells were stained with Hoechst and YFP was visualized. YFP transfected cells were imaged, and neurite lengths were measured. Polarized cells, in which one neurite was at least twice the length of the next longest neurite, were considered mature, whereas neurons with neurites that were similarly long were classified as immature. 45-60 neurons from 3 experiments were analyzed for each condition.

For isolated clonal cultures that allow both progenitors and differentiated neurons, following ex utero electroporation, dissociated cells were plated at low density ( 5000 cells/6 well plate) onto poly-D-lysine-coated coverslips under conditions that allow either division or differentiation (DMEM supplemented with $2 \%$ B27, $1 \%$ N2, $1 \%$ Na pyruvate, $1 \%$ glutamine, and 1\% NAC). Groups of transfected cells were imaged and cells in each clone were scored for YFP and dsRed expression. A total of 90-120 cells in three experiments were analyzed.

Quantification and statistical analysis. For cortical neuronal culture, micrographs of random areas of the coverslips were taken and subsequently analyzed with ImageJ for length per neurite. For IHC labeling, micrographs were taken of comparable sections from each embryo. At dorsal-most aspect of the cortex, one 100-120 $\mu \mathrm{m}$ bin was placed and labeled cells were counted in each of these bins. Data from all bins in each section were combined and average labeling index in equivalent sections from all animals obtained. Statistical analysis was performed by either ANOVA with Tukey's significant difference post hoc tests for experiments with more than two conditions or two-tailed unpaired Student's $t$ test on independent samples for experiments with only two conditions. All data are presented as means \pm SEM. $p<0.05$ was considered statistically significant $\left({ }^{*} p<0.05,{ }^{* *} p<0.01,{ }^{* *} p<0.005\right)$.

Protein coimmunoprecipitation. E14.5 dorsal telencephalon was homogenized in immunoprecipitation buffer ( $1 \% \mathrm{NP}-40,50 \mathrm{~mm}$ Tris- $\mathrm{HCl}, \mathrm{pH} 8.0$, $150 \mathrm{~mm} \mathrm{NaCl}$ ) containing protease inhibitors (Roche). The cellular lysate was shaken vigorously at $4^{\circ} \mathrm{C}$ for $15 \mathrm{~min}$, spun at $13,000 \mathrm{rpm}$ for $0.5 \mathrm{~h}$, and the supernatant was collected. Next, $30 \mathrm{mg}$ of this brain lysate was incubated with protein G Sepharose (GE Healthcare) beads for $30 \mathrm{~min}$ at 4 degrees to clear nonspecific binding. In parallel, $25 \mu \mathrm{l}$ of Sepharose was incubated for $1 \mathrm{~h}$ at room temperature (RT) with $10 \mu \mathrm{g}$ of Sox 4 antiserum, Sox 11 antiserum, or control IgG to conjugate antibodies to beads. Precleared lysate was then mixed with conjugated beads and incubated overnight at $4^{\circ} \mathrm{C}$. Samples were washed three times in immunoprecipitation buffer before proteins bound to protein $\mathrm{G}$ were eluted by boiling and subjected to Western blot analysis using Sox4, Sox11, Ngn1, Ngn2, Tbr1, Tbr2, Mash1, and Brn2 antiserum. CoimmunoprecipitationP experiments were repeated at least three times with new cortical lysates.

ChIP. To begin, antibodies were conjugated to beads: $25 \mu$ l of protein G Sepharose beads (GE Healthcare) was incubated with $10 \mu \mathrm{g}$ of Sox4 antiserum, anti-Sox11 antiserum, or IgG control for $1 \mathrm{~h}$ at RT. In parallel, 
A
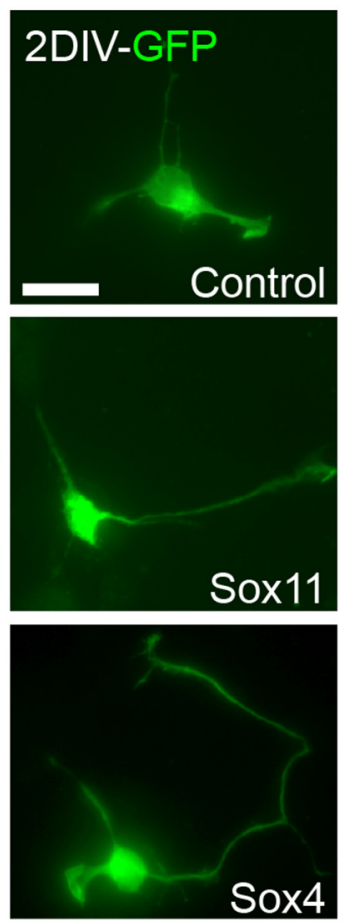

B

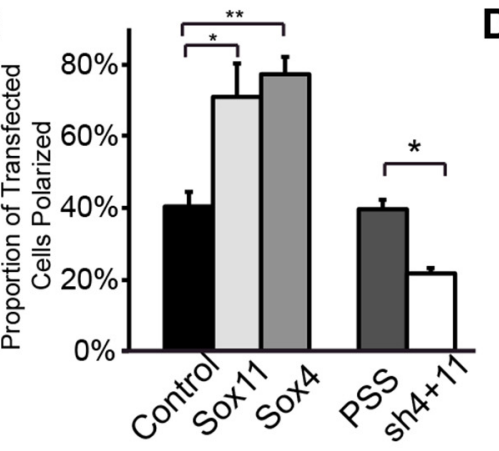

C

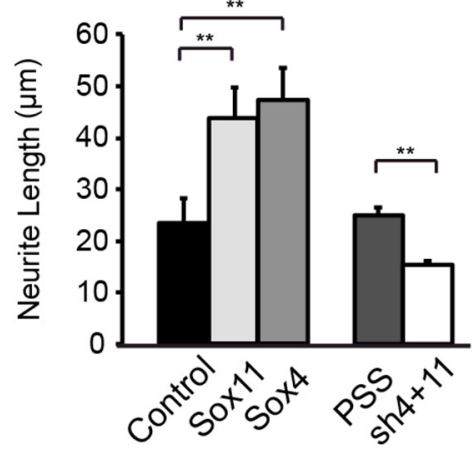

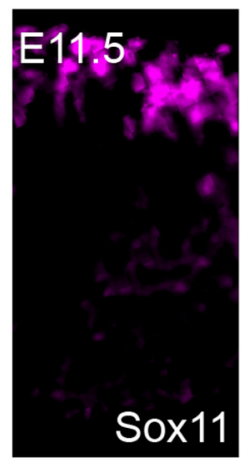
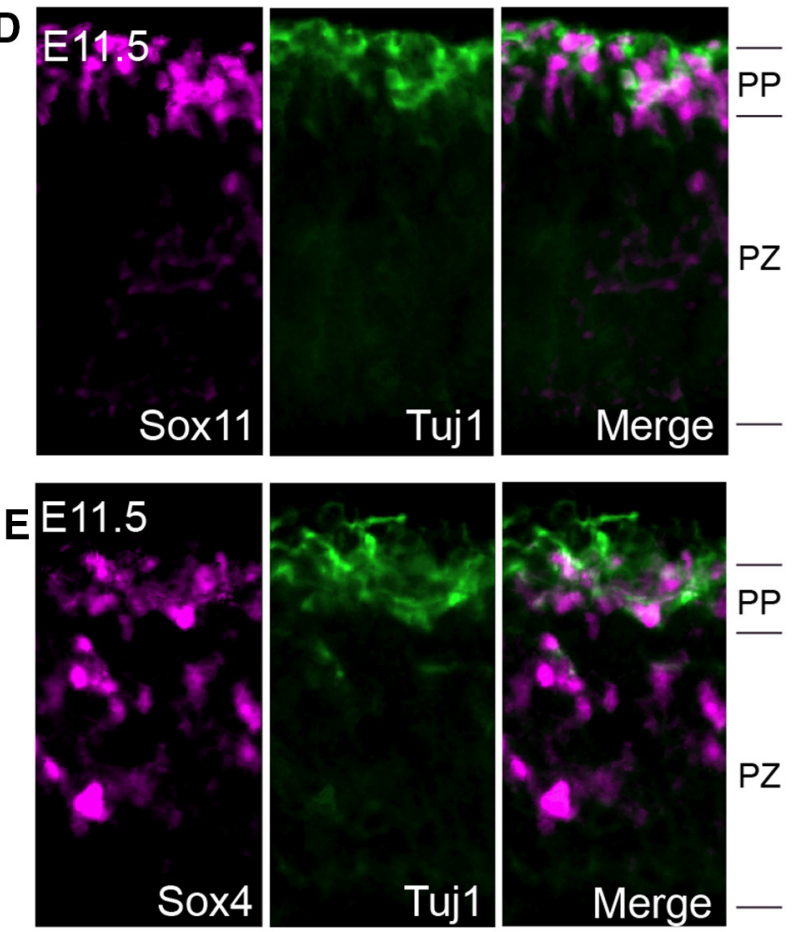

$\mathbf{F}$
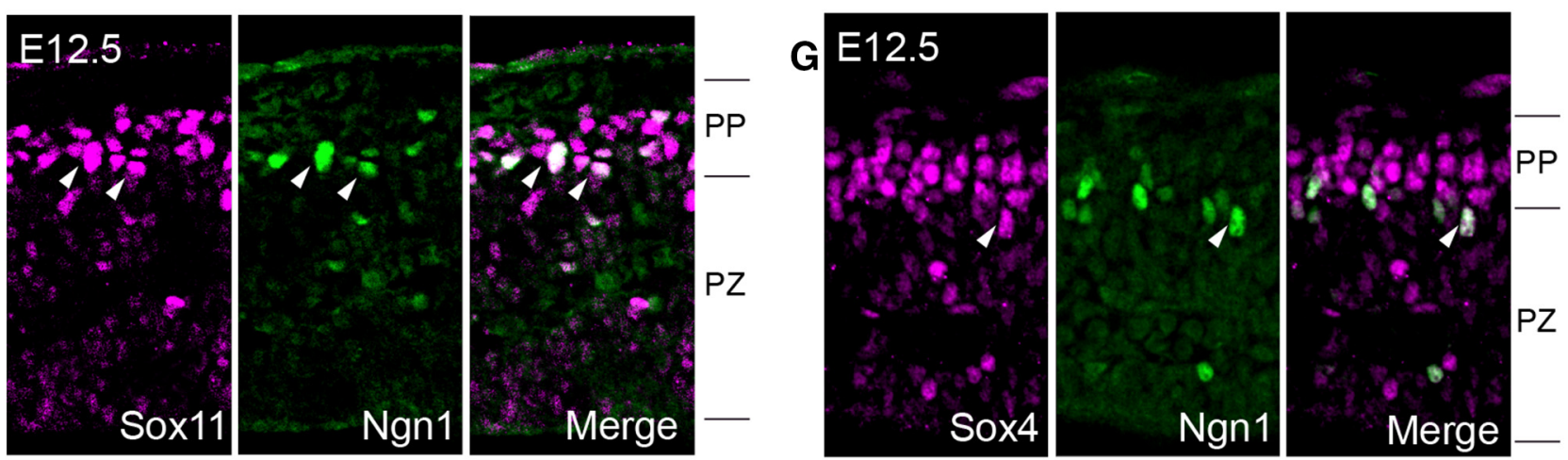

H
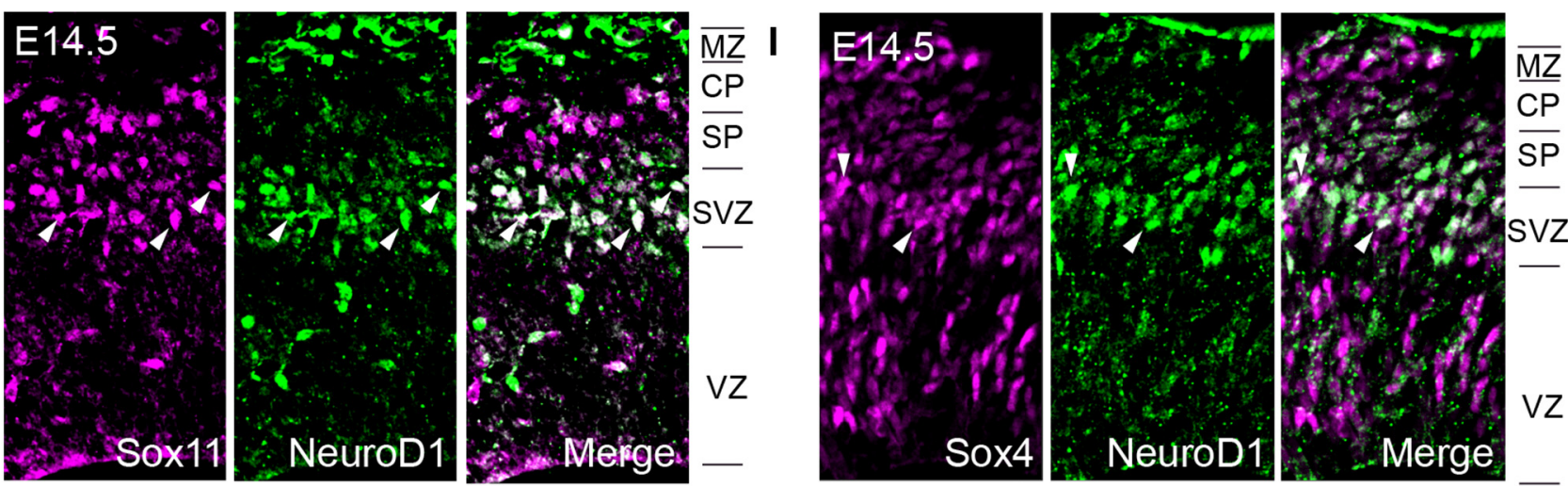

Figure 2. Sox11 and Sox4 promote neuronal differentiation but colocalize discretely with early neuronal markers. $\boldsymbol{A}$ - $\boldsymbol{C}$, In cultures of transfected differentiated cortical neurons and compared with control-transfected neurons ( $\boldsymbol{A}$, top), elevation of Sox 11 ( $\boldsymbol{A}$, middle) or Sox4 (A, bottom) resulted in higher proportions of polarized cells and increased neurite length, while LOF reduced the proportion of polarized cells and decreased neurite length $(\boldsymbol{B}-\boldsymbol{C})$. D-I, Expression of Sox11 and Sox4 (magenta) in conjunction with Tuj1 at E11.5 (D, $\boldsymbol{E})$, with Ngn1 at E12.5 (F, G), and with NeuroD1 at E14.5 (H, I) (green). Arrowheads in $\boldsymbol{F}$-I mark white coexpressing cells. Scale bars: $\boldsymbol{A}, 16 \mu \mathrm{m} ; \boldsymbol{D}, \boldsymbol{E}, 24 \mu \mathrm{m} ; \boldsymbol{F}, \boldsymbol{G}, 29 \mu \mathrm{m} ; \boldsymbol{H}, \boldsymbol{I}, 33 \mu \mathrm{m}$.

genomic DNA was prepared: $30 \mathrm{mg}$ of E14.5 cerebral cortex tissues was first cross-linked with a $1 \%$ formaldehyde solution to maintain protein/ DNA interactions. The tissue was then disrupted in lysis buffer $(50 \mathrm{~mm}$ HEPES-KOH, pH 7.5; 140 mM NaCl; 1 mM EDTA pH 8; 1\% Triton
$\mathrm{X}-100 ; 0.1 \%$ sodium deoxycholate; $0.1 \%$ SDS) containing protease inhibitors (Roche) for $30 \mathrm{~min}$ on ice before the genomic DNA was sonicated into 300-700 bp fragments. Approximately $25 \mu \mathrm{g}$ of genomic DNA was diluted 1:10 with IP dilution buffer (1\% Triton X-100; 2 mm EDTA, 

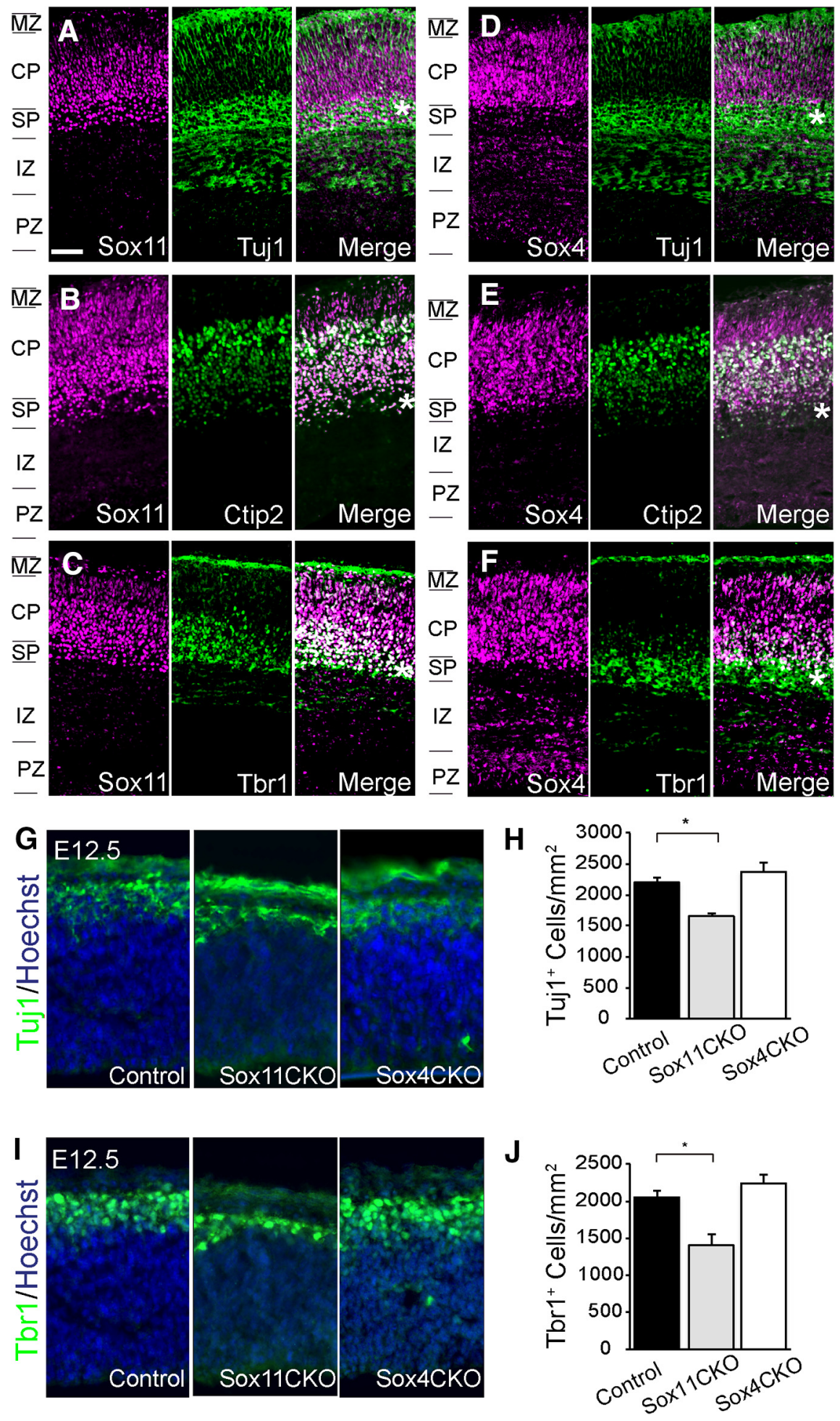

Figure 3. Sox11 and Sox4 label distinct and overlapping CP populations. $\boldsymbol{A}-\boldsymbol{F}$, Sox $11(\boldsymbol{A}-\boldsymbol{C})$ and Sox4 (D-F) (both magenta) colabeling with Tuj1 $(\boldsymbol{A}, \boldsymbol{D}),(\mathrm{Ctip} 2(\boldsymbol{B}, \boldsymbol{E})$ and $\operatorname{Tbr} 1(\boldsymbol{C}, \boldsymbol{F})$ (all green) in E17.5 mouse cerebral cortex. The asterisk placed in the SP in all samples highlights spatial differences between Sox11 and Sox4. $\mathbf{G}-\boldsymbol{J}$, At E12.5, both $\operatorname{Tuj}^{+}(\mathbf{G}, \boldsymbol{H})$ and $\operatorname{Tbr}^{+}(\boldsymbol{I}, \boldsymbol{J})$ cells are reduced in Sox $11{ }^{\mathrm{CKO} 0}$ cortex compared with control and Sox $4{ }^{\mathrm{CKO} 0}$ samples. Scale bars: $A-F, 64 \mu \mathrm{m} ; \boldsymbol{G}, \mathbf{I}, 30 \mu \mathrm{m}$.

Samples were incubated with $120 \mu$ l of elution buffer (1\% SDS; $100 \mathrm{~mm} \mathrm{NaHCO} 3$ ) for $15 \mathrm{~min}$ at $30^{\circ} \mathrm{C}$ and then centrifuged at $2000 \times g$ for 1 min. The supernatant was then digested with proteinase $\mathrm{K}$ overnight at $65^{\circ} \mathrm{C}$. The resultant DNA was then isolated with a phenol/chloroform extraction and concentrated with an ethanol precipitation. Levels of DNA were quantified by qRT-PCR (primer sequences: Tbr2-1: forward: 5'-GTACACCAGGATTGA TTCTCAG-3', reverse: 5'-GCTGGCTCTGC TAAACTCTAG-3'; Tbr2-2: forward: 5'-CCT GAGATGGTGAAATAAAATG-3', reverse: $5^{\prime}$ GGAGAATTATAGATCAGTGCAATG-3'; Tbr23: forward: 5'-GAAGCACATGTGTAGTCTTTG$3^{\prime}$, reverse: $5^{\prime}$-GAGAGCCACTCCATCTGAAC3'; NeuroD1-1: forward: 5'-ACGTGACCT GCCTATTTGTATG-3' , reverse: 5'-CTTTCTTT ACCTTTCCAGCTCG-3'; NeuroD1-2: forward: 5'-CAGAAGAAGCTCAAAGAGAAGC-3', reverse: 5'-GAGTTAGAAGAGGAACTGGAAAG3'; NeuroD1-3: forward: 5'-CAAAACCC GTTCTCCCCAAATC-3', reverse: 5'-GTGT ATTCTCTCGAGGTCTGTG-3'). Binding activity was normalized to levels in the IgG condition. ChIP experiments were repeated three times.

Transactivation experiments. A vector containing the NeuroD1 promoter, including Sox and Ngn target sites, cloned upstream of a luciferase reporter was generously supplied by Lori Sussel (Columbia University). A vector containing the Tbr2 promoter, including Sox, Ngn, and Tbr target sites, cloned upstream of a luciferase reporter was created in the laboratory using a vector generously provided by Takaki Miyata (Nagoya University) that contained a $3.8 \mathrm{~kb}$ Tbr2 promoter as a starting point. RT-PCR was performed to amplify an additional $2 \mathrm{~kb}$ of Tbr2 upstream sequence and that amplified fragment was cloned into the original vector to produce a plasmid with 5.8 $\mathrm{kb}$ of Tbr2 promoter sequence. The new vector was verified with sequencing. HEK 293 cells were transfected with luciferase vectors in combination with Sox 11 or Sox 4 alone or in combination with expression vectors for Ngn1 and Ngn2 (gift from Jane Johnson, University of Texas Southwestern Medical Center) and Brn2 and Tbr2 (Pasko Rakic, Yale University). Cells were harvested $24 \mathrm{~h}$ after transfection, cell extracts were prepared, and luciferase activity was measured using the Dual-Luciferase Reporter Assay System (Promega). Transactivation experiments were performed six times in duplicate.

\section{Results}

Cortical expression of Sox11 and Sox 4 during development

Although Sox11 and Sox4 have been implicated in the maturation in several neural systems, little was known about their expression and function during the development of the mouse cerebral cortex.

$\mathrm{pH} 8 ; 20 \mathrm{~mm}$ Tris- $\mathrm{HCl}, \mathrm{pH} 8 ; 150 \mathrm{~mm} \mathrm{NaCl}$ with protease inhibitor), mixed with the antibody-conjugated beads, and incubated overnight at $4^{\circ} \mathrm{C}$ with agitation. After incubation, the beads were washed 3 times in wash buffer (0.1\% SDS; $1 \%$ Triton X-100; 2 mm EDTA; 20 mM Tris-HCl, $\mathrm{pH} 8$; and $150 \mathrm{~mm} \mathrm{NaCl}$ ) and 1 time in final wash buffer (0.1\% SDS; $1 \%$ Triton X-100; 2 mм EDTA; 20 mм Tris-HCl, pH 8; and 500 mм NaCl).
Therefore, qRT-PCR with samples from dorsal telencephalon isolated at specific embryonic and postnatal ages was performed. This analysis reveals that levels of Sox 11 and Sox 4 are low at E10.5, when the neural tube is segregating regionally, and increase as the cerebral cortex is being seeded with neurons (E12.5- 

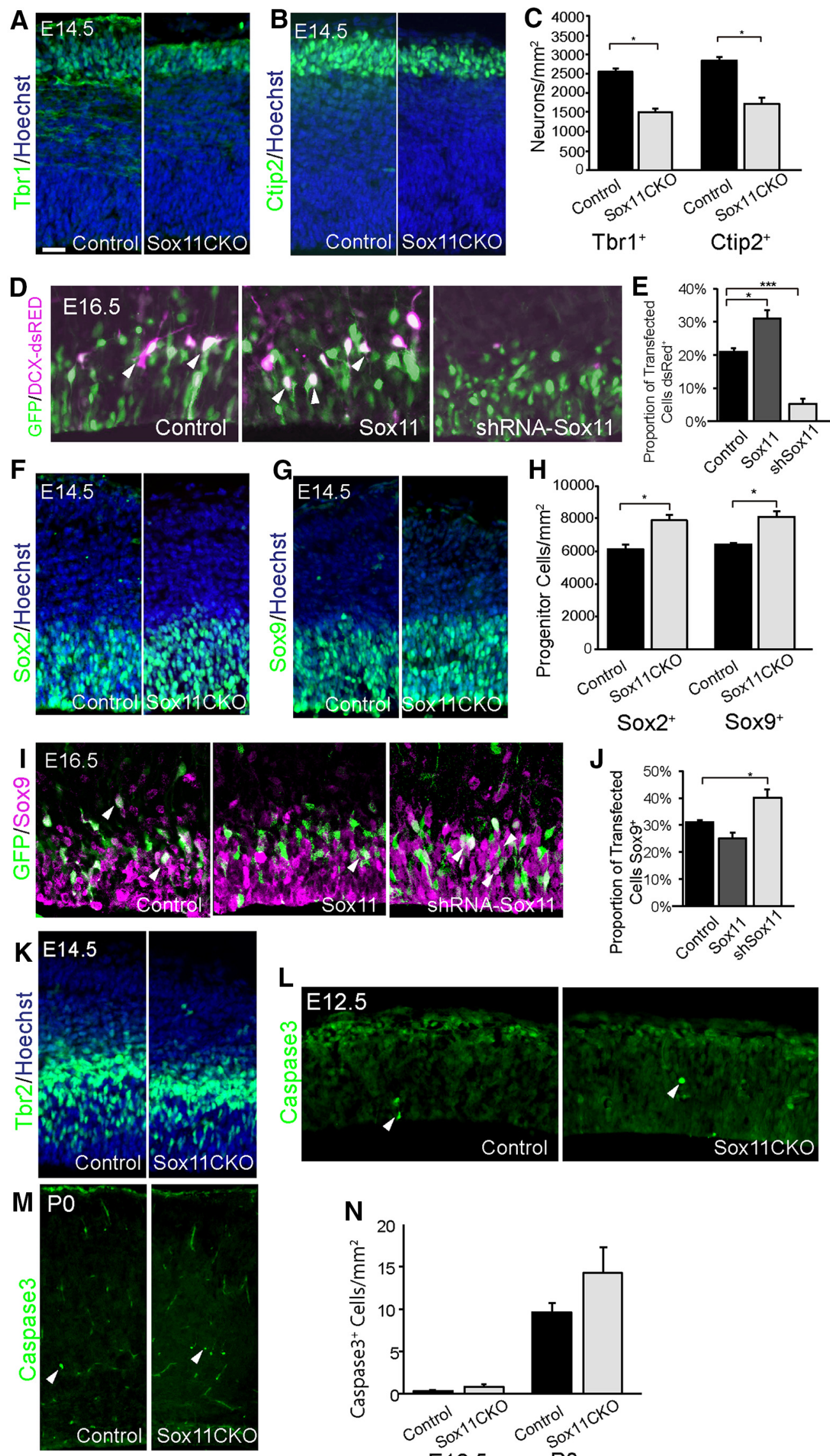

E12.5 P0

Figure 4. Manipulation of Sox11 shifts the abundance of differentiated neurons and apical progenitors. $\boldsymbol{A}-\boldsymbol{C}$, At E14.5, both Tbr ${ }^{+}(\boldsymbol{A})$ and $\mathrm{Ctip2}{ }^{+}(\boldsymbol{B})$ cells are reduced in Sox11 ${ }^{\mathrm{CK} 0}$ cortex compared with control. $\boldsymbol{D}, \boldsymbol{E}$, In utero electroporation that caused either elevation or reduction of Sox11 resulted in more or fewer transfected cells, (Figure legend continues.) 
E16.5). Levels of both Sox11 and Sox4 decrease as gestation ends and remain low throughout postnatal life (Fig. 1B). A similar pattern of Sox 11 and Sox 4 expression was observed in neurons in culture: levels were low in NSCs and immature neuronal cultures (1 DIV), increased as neurons differentiated (2-5 DIV), and then were low again in more mature cultures ( 8 DIV onwards) (Fig. $1 C)$. These expression results are similar to data from other neural systems (Potzner et al., 2010; Mu et al., 2012; Wang et al., 2013) and support the idea that both Sox 11 and Sox 4 promote the early differentiation of cortical neurons.

To determine the localization of Sox 11 and Sox4 during corticogenesis and at birth, IHC was performed using antisera specific for Sox 11 or Sox4 (Potzner et al., 2010). In these analyses, Sox11 was expressed as expected: present in differentiated neurons. Indeed, Sox 11 protein was present in the preplate (PP) early (E11.5), and the resultant marginal zone (MZ) and subplate (SP), as well as the condensing cortical plate $(\mathrm{CP})$ as development proceeds (E14.5-P0), with reduced levels postnatally (Fig. 1D-G). Therefore, qRT-PCR and IHC results for Sox11 during cortical development, as well as published results (Hoser et al., 2008; Bergsland et al., 2011), support a single, albeit transient, role for Sox11 in neuronal differentiation.

In contrast, examination of Sox 4 expression during corticogenesis produced an unexpected result. Although expressed in differentiated neurons, including some cells of the PP early and MZ, SP, and CP later, Sox $4^{+}$cells were also detected in more apical positions within the cerebral wall, consistent with the location of cortical germinal zones (Fig. $1 H-K$ ). Compared with Sox11's restricted expression within differentiated compartments, Sox4 was expressed in a smaller number of PP cells at E11.5 and in the MZ and CP at E14.5, as well as cells closer to the ventricle both early (E11.5) and later (E14.5) in cortical development (arrowheads in Fig. $1 L, N$ ). Differences in expression of Sox11 and Sox4 were also observed within the CP at E17.5: Sox $11^{+}$(green), Sox $4^{+}$(magenta), and Sox $11^{+}$Sox $4^{+}$(white) cells were present but differentially distributed (Fig. 1P,Q).

Therefore, although Sox11 and Sox 4 exhibited near-identical expression profiles in cortical extracts analyzed with qRT-PCR, IHC revealed unexpected differences in both protein and gene expression for these genes across the developing cerebral wall (Fig. $1 L-Q$ and set IDs MH3053 and MH916 at http://www.genepaint.org/). Together, each of these SoxC genes uniquely marks differentiated cells, whereas Sox 4 is exclusively present in germinal embryonic zones. In this study, Sox11's role in differentiated neurons will be studied first, followed by examination of specific actions of Sox 4 in cortical IPCs.

\section{Sox11 and Sox 4 act in discrete neuronal populations}

Roles for Sox 11 and Sox4 in cortical neuronal differentiation were first assessed in vitro. Cultures of differentiated neurons that express both SoxC genes (Fig. 1C) were transfected so that Sox11 or Sox4 levels were either elevated (gain-of-function: GOF)

\section{$\leftarrow$}

(Figure legend continued.) respectively, becoming $\mathrm{GFP}^{+}{ }^{+} \mathrm{dsRed}^{+}$neurons. $\boldsymbol{F}-\boldsymbol{H}, \mathrm{At} \mathrm{E} 14.5$, Sox ${ }^{+}(\boldsymbol{F})$ and Sox $9^{+}(\boldsymbol{G})$ cell numbers are elevated in Sox $11^{\mathrm{CKO}}$ cortex compared with control. $I, J$, In utero electroporation that caused either elevation or reduction of Sox11 resulted in no significant change for GOF and more transfected cells staining for the apical progenitor marker Sox9 for LOF. $\boldsymbol{K}, \mathrm{IHC}$ for Tbr2 revealed no change in the number of cortical cells expressing the protein in Sox $11^{\mathrm{CK} 0}$ mice compared with control (control: $6864 \pm 140 / \mathrm{mm}^{2}$, Sox11 CKO: $\left.6888 \pm 587 / \mathrm{mm}^{2}, p=0.96\right) . \boldsymbol{L}-\boldsymbol{N}$, At E12.5 $(\boldsymbol{L})$ and PO $(\boldsymbol{M})$, there was no change in activated Caspase3 staining in Sox $11^{\mathrm{CK} 0}$ cortex compared with control mice. Scale bars: $\boldsymbol{A}, \boldsymbol{B}, \boldsymbol{F}, \mathbf{G}, \boldsymbol{K}, 24$ $\mu \mathrm{m} ; D, 20 \mu \mathrm{m} ; I, 17 \mu \mathrm{m} ; L, 32 \mu \mathrm{m} ; M, 75 \mu \mathrm{m}$.
(Potzner et al., 2010) or reduced (loss-of-function: LOF) and neuronal characteristics were assessed. Analyses demonstrate that either Sox11 or Sox4 GOF increased neuronal polarization and neurite length, whereas LOF resulted in less mature neurons and shorter total neurite length (Fig. $2 A-C$ ). Therefore, both Sox 11 and Sox 4 are capable of enhancing neuronal differentiation in culture.

To better characterize Sox11- and Sox4-expressing cells in newly generated neurons of the cerebral wall, additional IHC was performed. Early in corticogenesis (E11.5), when the PP has just formed, analysis of expression reveals that both Sox $11^{+}$and Sox $4^{+}$cells are present in Tuj1 domains in the most superficial region of the cerebral wall, confirming expression of both genes in the PP (Figs. $1 L, 2 D, E)$. IHC to detect Neurogenin1 (Ngn1), a transient marker of newly differentiated neurons at E12.5 demonstrates that most $\mathrm{Ngn}^{+}$ cells also express Sox11, whereas a small proportion of $\mathrm{Ngn1}^{+}$cells express Sox4 (Fig. 2F,G). Further analysis performed slightly later in development, at E14.5, reveals that most NeuroD1 ${ }^{+}$cells express Sox11 (Fig. $2 H$ ), whereas a smaller proportion of NeuroD ${ }^{+}$cells express Sox4 (Fig. 2I). These analyses support the idea that specific populations of neurons express Sox 11 versus Sox 4 within the forming cortex.

Additional analyses were performed at E17.5, when the CP is substantial and cells that will occupy all layers are present. Both Sox $11^{+}$and Sox $4^{+}$cells are detectable in cellular zones marked by the neuron-specific Tuj1 antiserum, although Sox11 staining extends deeper into Tuj1 domains, specifically the deepest CP and SP, than does Sox4 (Fig. $3 A, D$ ). Costaining with Ctip2, a marker of cells in the deep CP destined to populate layer $\mathrm{V}$ and VI (Fig. $3 B, E$ ), or Tbr1, a marker of deepest CP cells that will become layer VI and SP, which is derived from the PP (Fig. $3 C, F$ ), reveals that Sox 11 is present in the deep CP and SP, whereas Sox 4 is expressed more superficially (compare staining of Sox11 or Sox 4 to the fixed position of the asterisk in each panel).

To investigate the function of Sox 11 and Sox 4 in neuronal populations, mice mutant for each gene in the cortex were analyzed. In these mice, Sox 11 or Sox 4 coding sequence, flanked by loxP recombination sites (Penzo-Méndez et al., 2007; Bhattaram et al., 2010), was deleted with a Cre recombinase expressed from the Emx1 promoter (Gorski et al., 2002). Because Emx1 is expressed in all neuroepithelial cells of the forming pallium (Yoshida et al., 1997), conditional mutants (Sox $11^{\text {CKO }}$ and Sox $4{ }^{\text {CKO }}$ ) lack Sox 11 or Sox 4 in all cells derived from cortical germinal zones. Therefore, all excitatory neurons of the cortex will be mutant for Sox11 or Sox4 in these mice. Early in corticogenesis, at E12.5, Tuj1 staining was reduced in Sox $11{ }^{\mathrm{CKO}}$ mutant compared with control or Sox $4{ }^{\mathrm{CKO}}$ (Fig. $3 G, H$ ), indicating that there were either fewer or less mature neurons present in the PP when Sox11 was absent. At the same age, the number of Tbr $1^{+}$cells was also significantly lower in Sox $11^{\mathrm{CKO}}$ mutant cortex compared with wild-type or Sox $4^{\mathrm{CKO}}$ (Fig. $3 I, J$ ). Because these data support a role for Sox11, but not Sox4, in the production of PP neurons, which eventually populate the MZ and SP, further analyses will focus on how Sox11 acts in early-born differentiated neurons.

The consequences of Sox 11 action were also examined later in cortical development. At E14.5, staining with the deep layer markers Tbr1 and Ctip2 was reduced in Sox $11^{\mathrm{CKO}}$ compared with wild-type cortex (Fig. 4A-C). In vivo GOF manipulation of Sox 11 paralleled mutant data: high levels of Sox11 increased and reduction of Sox11 reduced neuron number, respectively (Fig. $4 D, E$ ). Therefore, Sox 11 promotes neuronal differentiation of early-born neurons.

There are two obvious explanations for the shifts in proportions of differentiated neurons when Sox11 levels were perturbed: change in the balance between progenitor division and 
A

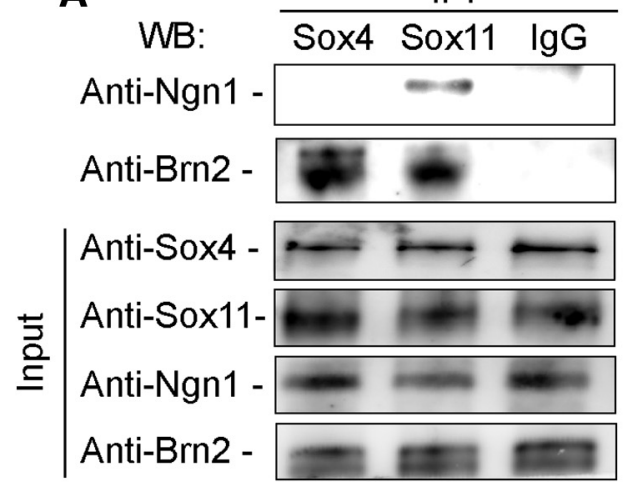

B Evolutionary Conserved Regions Promoter UTRS Exons Introns

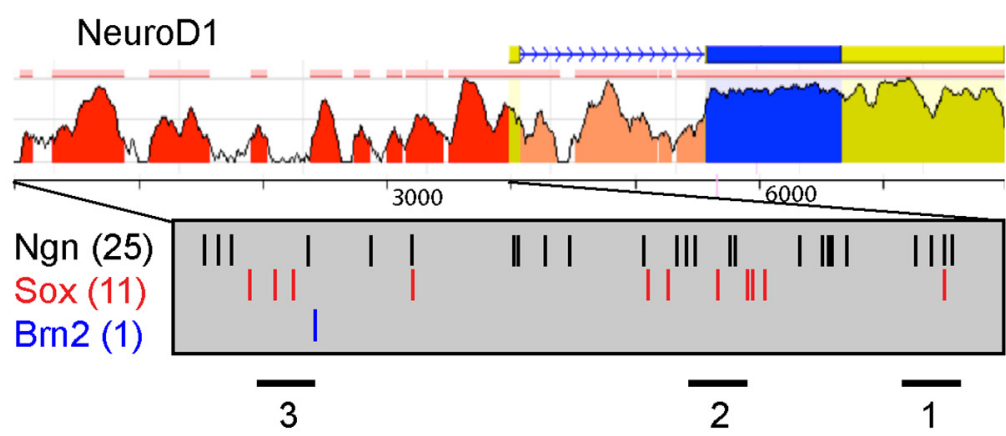

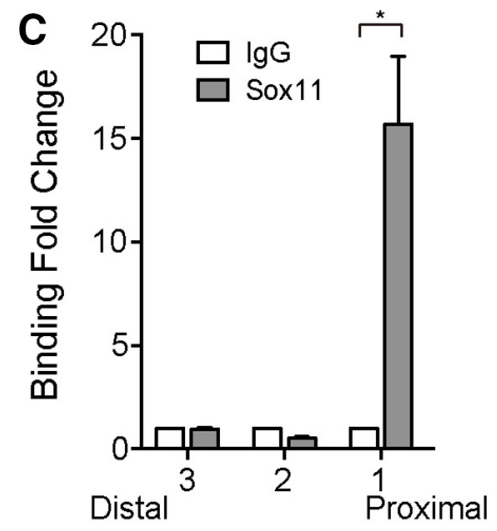
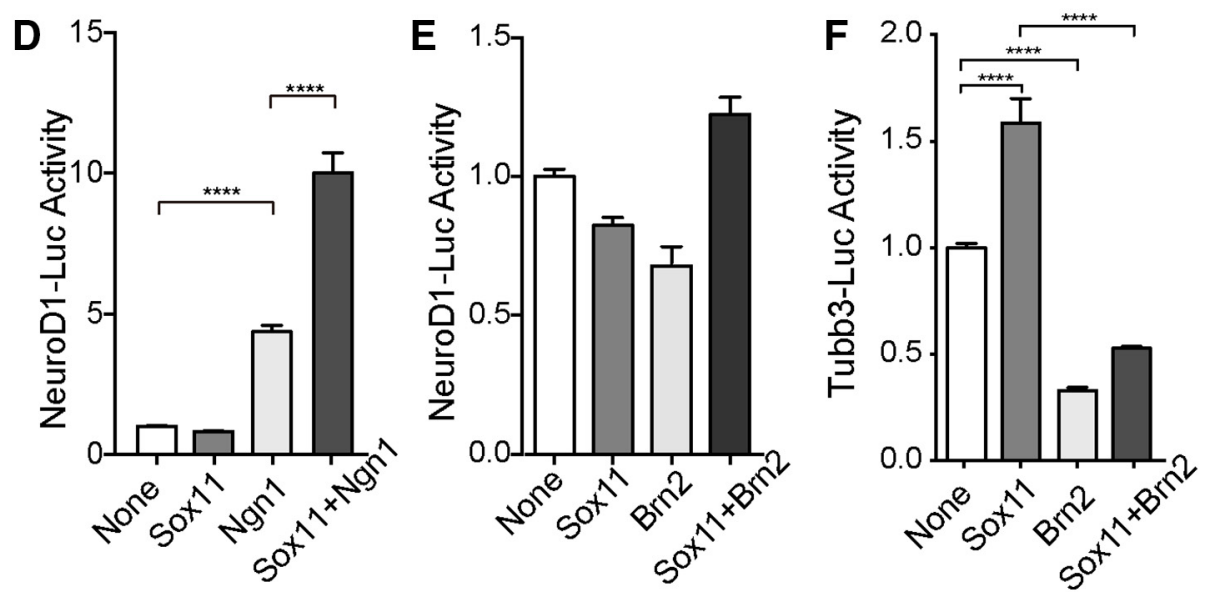

Figure 5. Sox11's partner proteins and targets in differentiated neurons. A, Coimmunoprecipitation was performed using E14.5 cortical lysate in which antisera for Sox4 or Sox 11 or a control lgG was used to pull down protein complexes before Western blotting for Ngn1 and Brn2. Only Sox11 binds Ngn1; both Sox4 and Sox11 bind Brn2. B, The NeuroD1 locus, with the genomic organization indicated at the top and levels of conservation between mouse and human indicated below by the height of the peaks. The promoter has been magnified in the gray box, with possible Ngn (black), Sox (red), and Brn2 sites indicated. Regions 1-3, studied with ChIP, are indicated by bars at the bottom. C, ChIP using E14.5 cortex and primers specific for proximal (1), middle (2), and distal (3) regions of the NeuroD1 promoter (bars below gray box in $\boldsymbol{B}$ ) reveals Sox 11 is capable of binding to region 1 but not 2 or 3 of the NeuroD1 promoter. $\boldsymbol{D}, \boldsymbol{E}$, Transactivation experiments reveal that the NeuroD1 promoter-luciferase construct is not responsive to Sox11 alone, is moderately responsive to Ngn1 alone, and is significantly elevated in the presence of either Sox11 with Ngn1 (D). In contrast, coexpression of Sox11 with Brn2 does not promote NeuroD1 expression (E).F, Transactivation experiments reveal that the Tubb3 promoter-luciferase construct is responsive to Sox11 alone but is suppressed by both Brn2 alone and Brn2 in combination with Sox11.

neuronal differentiation or alteration in cell death. Analyses revealed that numbers of Sox $2^{+}$and Sox $9^{+}$progenitors were elevated when Sox11 was absent in the cortex at E14.5 (Fig. 4F-H). Furthermore, in vivo manipulation of Sox 11 followed by examination of the apical progenitor marker Sox 9 revealed no statistically significant change in Sox $9^{+}$-transfected cells in GOF brains but an increase in the proportion of Sox $9^{+}$-transfected cells when the level of Sox11 levels was reduced (Fig. 4I,J). Finally, compared with shifts in apical progenitor populations, numbers of Tbr ${ }^{+}$IPCs were unaffected by absence of Sox 11 when examined at E14.5 (control: $6864 \pm 140 / \mathrm{mm}^{2}$, Sox11 CKO: $6888 \pm$ $587 / \mathrm{mm}^{2}, p=0.96$ ) (Fig. $4 K$ ). Interestingly, no statistically significant changes in levels of cell death were observed when Sox11 were absent in early (E12.5) or late (P0) cortex (Fig. $4 L-N)$. In sum, Sox 11 appears to promote the genesis of populations of early-born cortical neurons at the expense of apical progenitors.

\section{Sox11 binding partners and target genes in} differentiated neurons

Sox proteins require partner proteins to bind DNA and affect target gene expression. Although a number of Sox partner proteins have been identified and validated (Wilson and Koopman, 2002; Bernard and Harley, 2010), nothing is known about inter- actions of SoxC proteins in neurons of the mammalian cerebral cortex. Selective colocalization of Sox11 with transcription factors essential for cortical neuronal maturation, such as Ngn 1 and NeuroD1, however, was noteworthy (Fig. $2 F, H$ ). Examination of whether Sox11 can interact with Ngn1 during mouse cortical development was performed via coimmunoprecipitation using protein extract derived from E14.5 cortex. Data from these experiments demonstrate that Sox11 selectively binds Ngn1 and that both Sox 4 and Sox11 bind the POU domain protein Brn2 (Fig. $5 A$ ). Other transcription factors expressed in differentiated cortical neurons, such Tbr1 and Mash1, did not bind Sox11 in this assay (data no shown). Therefore, Ngn1 is a potential binding partner with Sox11 during neuronal differentiation.

NeuroD1, one of the earliest markers of neuronal differentiation in the forebrain, is regulated by Ngn1 (Schwab et al., 1998; Ge et al., 2006; Kovach et al., 2013) and enriched in Sox $11^{+}$ neurons (Fig. $2 H, I$ ). To determine whether Sox11 might bind within NeuroD1 regulatory sequences, ChIP was performed. Sequence analysis revealed three domains (see bars numbered 1-3 beneath magnified promoter) within the promoter that contained Ngn, Sox, and Brn2 binding motifs (Fig. 5B). Focusing on these regions, ChIP data demonstrated that Sox11 selectively binds to a proximal domain, region 1 , of the NeuroD1 promoter (Fig. $5 B, C$ ). To determine whether Sox11 and Ngn1 can affect 

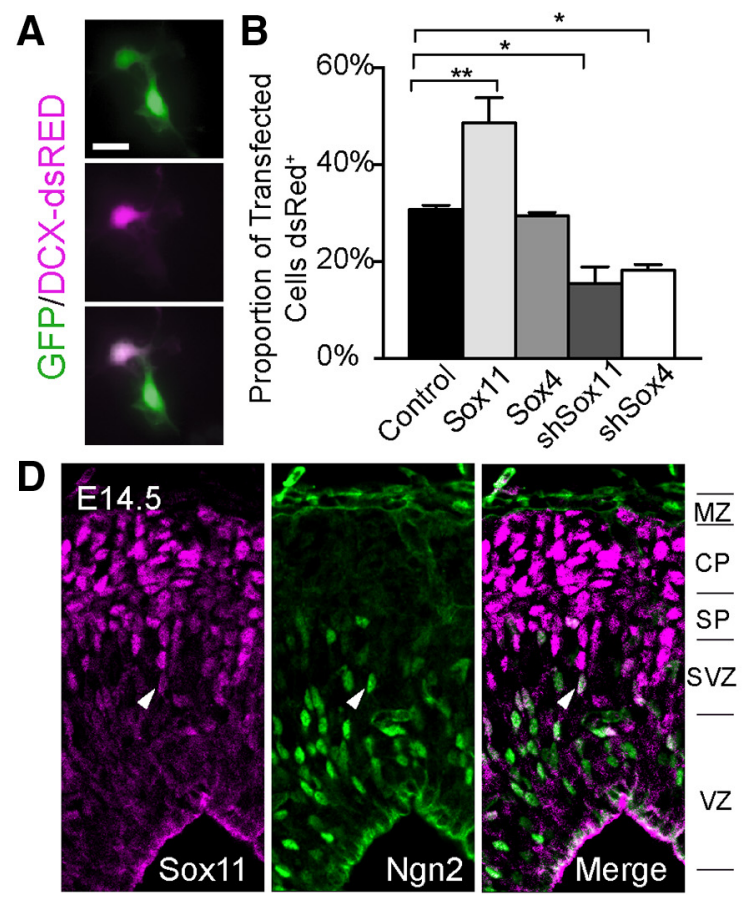

C

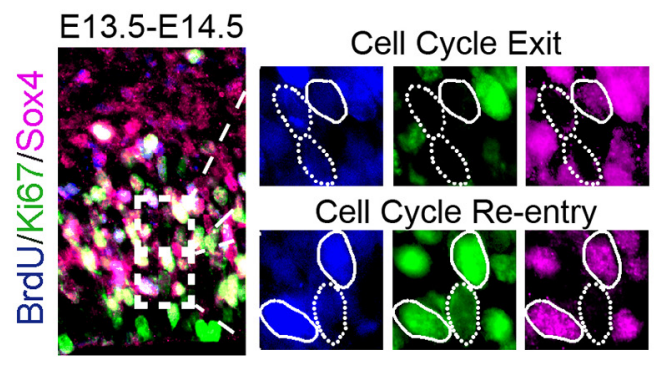

E
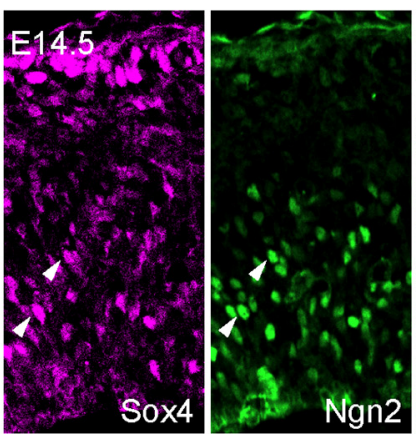

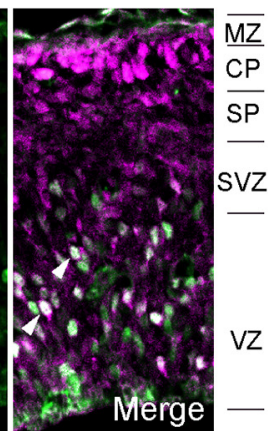

Figure 6. Sox 4 is present in dividing cortical cells and selectively colabels with $\mathrm{Ngn} 2 . A, B$, In clonal cultures that allow both progenitor division and neuronal differentiation, cells transfected with a ubiquitous YFP plasmid and a neuron-specific dsRed plasmid may be a Green ${ }^{+}$Magenta ${ }^{-}$progenitor or a Green ${ }^{+}$Magenta ${ }^{+}$neuron $(\boldsymbol{A})$. Quantification reveals that in this culture system, elevation of Sox 11, but not Sox4, results in a higher proportion of transfected cells becoming neurons, whereas reduction of Sox 11 or Sox4 results in a smaller proportion of transfected cells becoming neurons (B). C, E14.5 cortex, prepared for mitotic analysis with cells labeled for BrdU (blue, injected at E13.5) and counterstained with Ki67 (green) and Sox4 (magenta). BrdU ${ }^{+}$Ki67 ${ }^{-}$cells were dividing at E13.5, but had exited the cell cycle by E14.5, whereas BrdU ${ }^{+} \mathrm{Ki}_{67}{ }^{+}$cells remained mitotically active at E14.5. Sox $4^{+}$cells (solid circles in C) tended to continue dividing, whereas Sox4 ${ }^{-}$ cells (dashed circles in $\boldsymbol{C}$ ) tended to exit the cell cycle. $\boldsymbol{D}, \boldsymbol{E}$, Costaining of Sox11 (D) and Sox4 (E) (both magenta) with Ngn2 (green) at E14.5 reveals little overlap with Sox11 but considerable colabeling with Sox4. Arrowheads indicate white cells expressing both Sox11 or Sox4 and Ngn2. Scale bars: $\boldsymbol{A}, 16 \mu \mathrm{m} ; \boldsymbol{C}-\boldsymbol{E}, 20 \mu \mathrm{m}$.

NeuroD1 transcriptional activity, an expression vector consisting of the NeuroD1 promoter that includes region 1 linked to a luciferase gene was used. Cells were transfected with this NeuroD1luciferase expression vector in combination with an empty vector as a control or with expression vectors for Sox 11 or Ngn 1 alone or Sox11 and Ngn1 together. Luciferase levels were low in the control condition or when Sox 11 was transfected alone. Consistent with a proneural function, Ngn1 elevated luciferase levels considerably. Reporter gene levels were significantly higher, however, when Sox11 were combined with Ngn1, revealing synergistic transactivation of the NeuroD1 promoter (Fig. 5D). Interestingly, another transcription factor capable of binding SoxC proteins, Brn2, had no effect on NeuroD1-driven expression (Fig. $5 E$ ) but suppressed another Sox11-responsive gene, Tubb3, either alone or in combination with Sox11 (Fig. 5F). These data support a model in which NeuroD1's activation by Ngn 1 during corticogenesis is likely to occur in partnership with Sox11. Similar to other analyses that show complex regulation of neuronal genes over time (Ma et al., 1999; Shim et al., 2012), the actions of Sox11 in differentiated neurons are multifaceted. Sox 11 partners with Ngn1 to activate NeuroD1 and can also activate Tubb3, but only when the level of Brn2 is low. Therefore, Sox11 promotes neuronal differentiation in a tightly choreographed and nuanced manner.

\section{Sox 4 controls IPC specification}

Attention was next directed at understanding the identity of the Sox $4^{+}$cells holding apical positions within the cerebral wall. To start, additional neuronal culture experiments were performed. Rather than growing cells under the conditions used previously that only support the survival differentiated neurons (Fig. 2A-C), however, alternative culture conditions were used that maintain both cortical progenitor cells and differentiated neurons (Qian et al., 2000). In this clonal culture system, cells were transfected with a ubiquitous GFP, a neuron-specific DCX-dsRed, and either an inert plasmid or Sox 4 or Sox11 GOF or LOF vectors. Transfected cells were scored either as neuronal progenitors $\left(\mathrm{Green}^{+} \mathrm{Magenta}^{-}\right)$or differentiated neurons $\left(\right.$ Green $^{+}$Magenta $^{+}$) $($Fig. 6A). In this experimental paradigm, Sox11 GOF promoted neuronal differentiation of transfected cells, just as it had previously (Fig. $2 A-C$ ), but Sox4 GOF produced results that were no different from control-transfected cells (Fig. 6B). Conversely, both Sox 11 and Sox 4 LOF reduced the proportion of transfected cells differentiating into neurons (Fig. $6 B)$. Therefore, consistent with discrete expression profiles, Sox11 and Sox4 appear to direct different cellular trajectories.

The presence of Sox $4^{+}$cells within the apical cerebral wall (Fig. $1 H, I, L, N)$ was surprising. Given their location just superficial to the VZ, two possibilities existed regarding the identity of these Sox $4^{+}$cells: (1) Sox $4^{+}$cells are progenitors within cortical proliferative zones, most likely the SVZ because of the Sox $4^{+}$ cells' position away from the ventricle, or (2) Sox $4^{+}$cells are newly differentiated neurons that are transiently present in the germinal zone as they migrate superficially to the CP. To distinguish between these possibilities, apical Sox $4^{+}$cells were characterized. To start, the mitotic status of Sox $4^{+}$cells was determined. In this analysis, E13.5 timed pregnant mice were injected with the nucleotide analog BrdU and labeled cortical cells were examined $24 \mathrm{~h}$ later. Cells within the SVZ proliferative zones were scored for the coincidence of staining for Sox 4 with BrdU, which indicated that cells were replicating DNA at E13.5, and Ki67, revealing that cells were actively dividing at E14.5 (Fig. $6 C)$. Quantification of BrdU cells in cortical germinal zones re- 


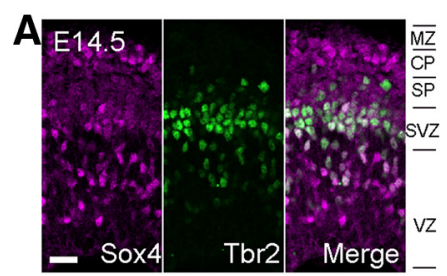

D

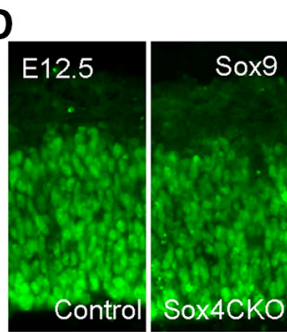

G

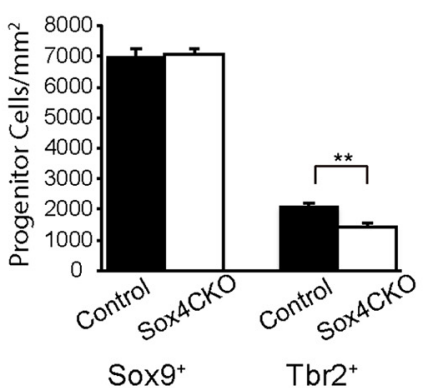

$\mathrm{Tbr}^{+}$

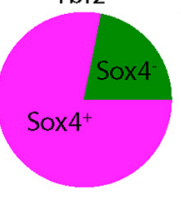

E

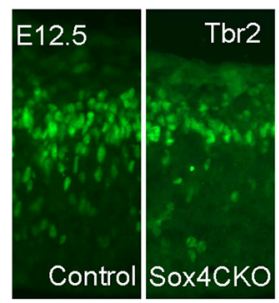

B

H

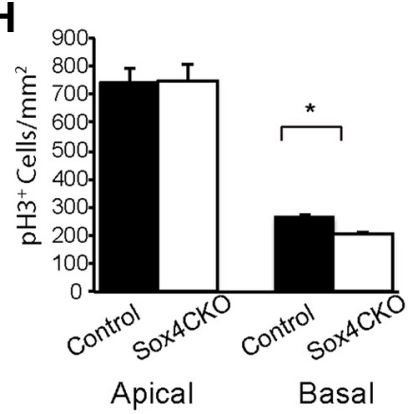

F

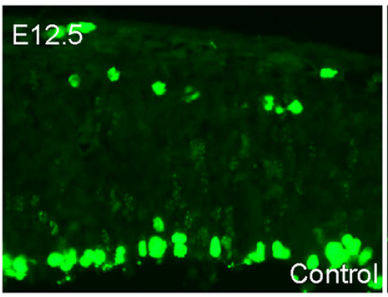

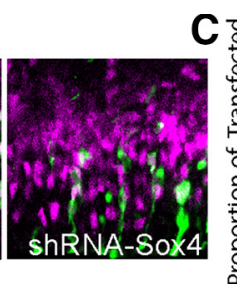

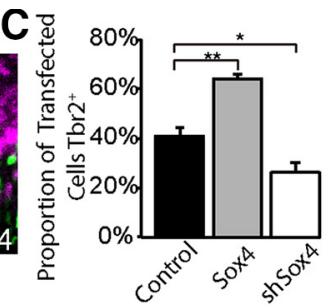

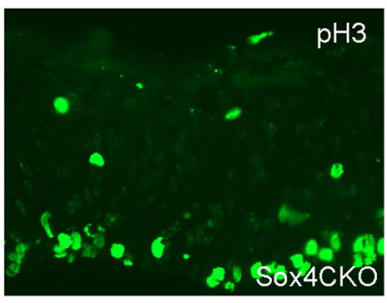

I

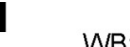

IP:

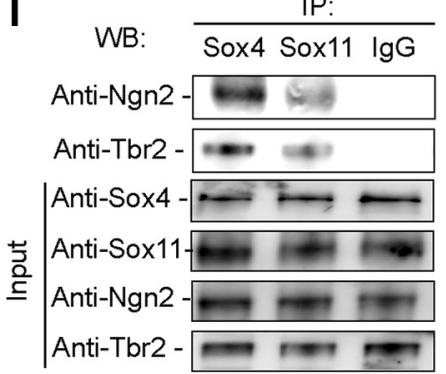

J

Tbr2

Evolutionary Conserved Regions Promoter UTRs Exons Introns
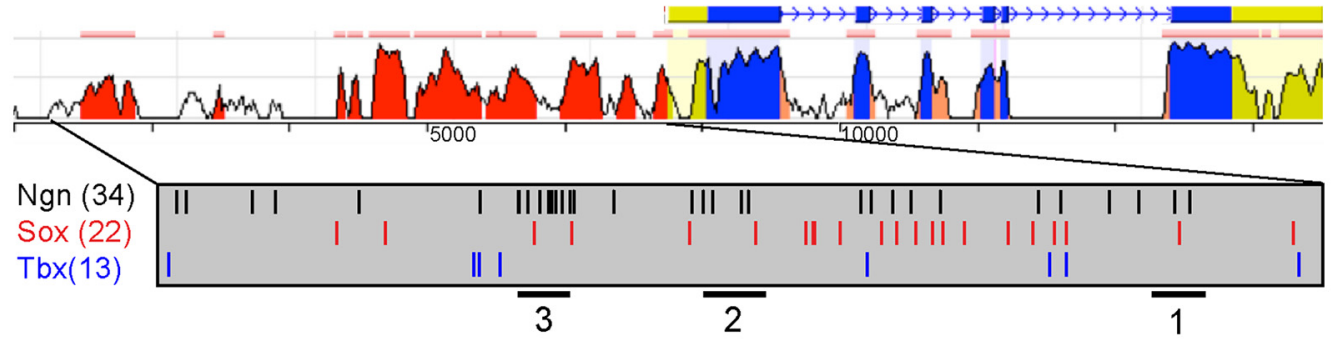

K

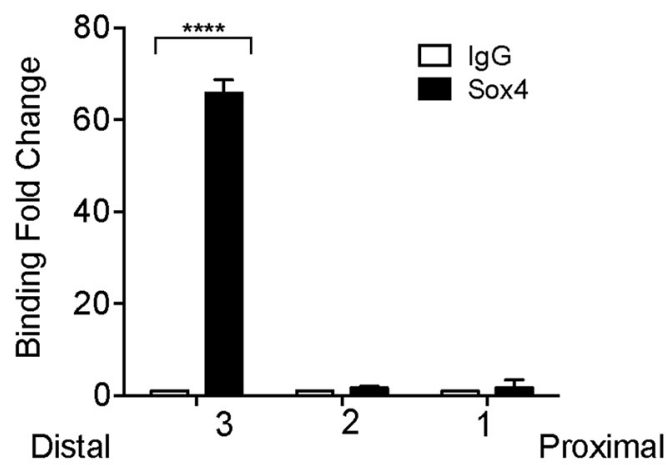

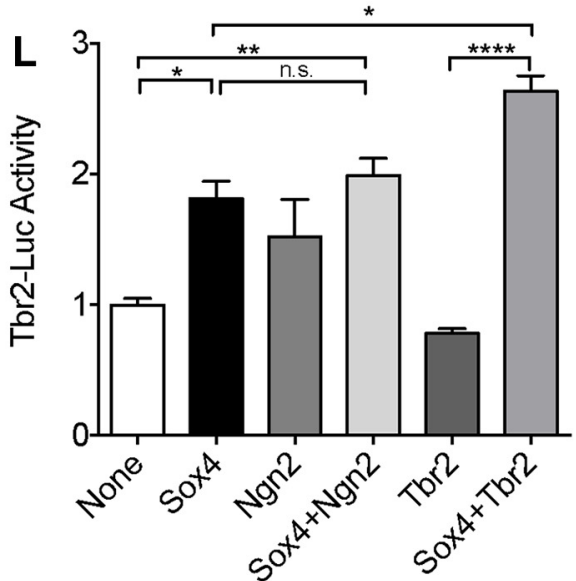

Figure 7. Sox 4 is present in the SVZ and affects IPCS. $\boldsymbol{A}$, Sox 4 is coexpressed with the SVZ marker Tbr2 at E14.5; $>75 \%$ of Tbr2 ${ }^{+}$cells are also Sox4 ${ }^{+}$. B, C, Elevation of Sox4 results in increased $\mathrm{Tbr2}^{+}$transfected cells, whereas reduction of Sox4 reduced Tbr2 ${ }^{+}$transfected cell number. D, E, G, E12.5 control or Sox4 ${ }^{\mathrm{CK} 0}$ mouse cortex stained with Sox 9 , a marker of apical progenitors, or Tbr2, a marker of IPCs, reveals no change in Sox $9^{+}$but decreased Tbr2 ${ }^{+}$cells in the Sox4 mutant cortex. $\boldsymbol{F}, \boldsymbol{H}$, Phospho-histone-H3 staining of control or Sox ${ }^{\text {CK0 }}$ mouse cortex reveals decreased basal but not apical progenitors. I, Coimmunoprecipitation using E14.5 cortical lysate in which antibodies for Sox 4 or Sox 11 or a control lgG was used to pull down before Western blotting was performed with antisera specific for Ngn2 or Tbr2. Sox4 preferentially binds Ngn2 and Tbr2 compared with Sox11. J, The Tbr2 locus, with genomic organization mapped above and levels of conservation between mouse and human indicated by the height of the peaks beneath. The promoter is magnified in the gray box, with possible Ngn (black), Sox (red), and Tbx (blue) sites indicated. Regions 1-3, studied with ChIP, are indicated by bars beneath. $\boldsymbol{K}$, ChIP using E14.5 cortical lysate and primers specific for proximal (1), middle (2), and distal (3) regions of the Tbr2 promoter (bars in $\boldsymbol{J}$ ) reveals that Sox4 is capable of binding to region 3, but not 1 or 2, of the Tbr2 promoter. $\boldsymbol{L}, \boldsymbol{M}$, Transactivation studies reveal that Sox4 alone activates the (Figure legend continues.) 


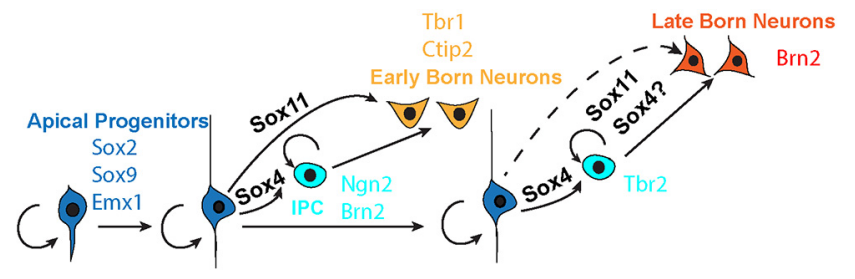

Figure 8. During corticogenesis, Sox4 expands IPC pools, whereas Sox 11 and Sox4 promote discrete populations of neurons. Shown is a schematic of the cellular transitions that occur during cerebral cortical development as apical progenitors in the VZ transition to IPCs within the SVZ via Sox4, to early-born neurons of the SP and deep CP via Sox 11, and to late born neurons via both Sox4 and Sox11.

vealed that a higher proportion of Sox $4^{+}$cells $(75.7 \pm 4.7 \%)$ were in the cell cycle compared with Sox $4^{-}$cells $(44.1 \pm 4.9 \%)$. This result demonstrates that Sox 4 expression tracks with cell division for apically located Sox ${ }^{+}$cells. Costaining with Ngn2, a bHLH transcription factor present in newly formed IPCs (Scardigli et al., 2003), revealed that few Sox $11^{+}$cells but many Sox $4^{+}$ cells express Ngn2 (Fig. 6D,E). Therefore, it seems likely that Sox4 uniquely marks IPCs within the SVZ.

To ascertain whether this was the case, colocalization of Sox 4 with Tbr2, the definitive marker of IPCs within the cortical SVZ (Ochiai et al., 2009), was examined. Coincidence between Sox4 and Tbr2 was striking: $>75 \%(78.4 \pm 0.9 \%)$ of Tbr ${ }^{+}$cells also expressed Sox4 (Fig. 7A). To examine Sox4's function in IPCs, Sox4 levels were manipulated in vivo and the consequences of GOF or LOF were assessed. For this experiment, cortical cells were transfected with GFP, along with either a control plasmid or vectors to induce Sox 4 GOF or LOF, and transfected cortex was stained for Tbr2. This analysis revealed that less than half of control-transfected cells expressed Tbr2 $(40.95 \pm 3.3 \%)$ and that significantly more GOF $(63.99 \pm 1.56 \%)$ and significantly fewer LOF $(26.22 \pm 4.2 \%$ ) cells expressed Tbr2 (Fig. 7 B, C). Together, these results demonstrate that Sox 4 levels correlate with the presence of Tbr2 in transfected cells of the cortical SVZ, exposing a hitherto unknown function of this SoxC family member in IPCs.

To further characterize Sox4 function in progenitor cells, mice conditionally mutant for Sox 4 in the nervous system were analyzed. Early in corticogenesis, at E12.5, when the vast majority of cells in the developing cortex are progenitors, there is no change in Sox $9^{+}$cells but a striking reduction in the number of Tbr2 ${ }^{+}$ IPCs when Sox4 is absent (Fig. $7 D, E, G$ ). Similarly, levels of phosphorylated histone- $\mathrm{H} 3$, an indicator of extant cell division, were significantly decreased in basal but not apical progenitors when Sox4 was lacking (Fig. $7 F, H$ ). These LOF data also support a model in which Sox4 promotes IPC identity.

\section{Sox4 binding partners and target gene in IPCs}

To investigate how Sox 4 might act in IPCs, binding of Sox 4 with Ngn2 or Tbr2 was assessed using coimmunoprecipitation with protein extract derived from E14.5 cortex. Data reveal that Sox 4 interacts with both Ngn 2 and Tbr2 and that these interactions are more robust for Sox4 than Sox11 (Fig. 7I). Other transcription factors expressed in cortical development, such as Ngn1, Tbr1, and Mash1, failed to bind Sox4 in this assay (data not shown).

\section{$\leftarrow$}

(Figure legend continued.) Tbr2 promoter and that this activation is maintained when Sox4 and Ngn2 are cotransfected. In contrast, transfection of Tbr2 does not affect levels of the Tbr2driven luciferase alone, but Tbr2 and Sox4 together significantly increase the level of Tbr2 expression. Scale bars: $\boldsymbol{A}, 24 \mu \mathrm{m} ; \boldsymbol{B}, 17 \mu \mathrm{m} ; \boldsymbol{D}-\boldsymbol{F}, 19 \mu \mathrm{m}$.
Therefore, these data identify Ngn2 and Tbr2 as potential partner proteins for Sox 4 during corticogenesis.

Given the coincidence of Sox 4 with Ngn2 (Fig. 6D,E) and Tbr2 (Fig. 7A) and the finding that Tbr2 is a target of Ngn2 (Ma et al., 1999; Kovach et al., 2013), the possibility of a direct interaction for Sox 4 at the Tbr2 locus was assessed. To this end, ChIP was performed focusing on regions of the Tbr2 promoter (see bars numbered 1-3 beneath magnified promoter) that are well conserved from human to mouse and also contain Sox, Ngn, and Tbox consensus binding motifs (Fig. 7J). ChIP data demonstrate that Sox 4 binds a distal domain, region 3, of the Tbr2 promoter (Fig. $7 \mathrm{~J}, K)$. Next, transactivation experiments were performed and revealed that Sox4, but not Ngn2, is capable of elevating Tbr2 expression alone and that cotransfection of both Sox 4 and Ngn2 resulted in levels similar to Sox 4 alone. The lack of synergy between Sox 4 and Ngn 2 suggests that these molecules act separately in IPCs, both converging on Tbr2. In contrast, whereas expression of Tbr2 alone had no effect on Tbr2-luciferase levels, when Sox 4 and Tbr2 were both present, levels were elevated over Sox 4 alone (Fig. $7 L$ ). Therefore, a molecular pathway involving both Ngn 2 and Tbr2 appears to exist for Sox4's actions in promoting IPC identity.

\section{Discussion}

Neurogenesis, the process by which dividing neuroepithelium produces differentiated neurons, involves stereotyped molecular pathways that occur in every region of the nervous system in every animal. As the brain develops, genes are initially expressed that promote mitosis. When a cell receives environmental or genetic instruction to cease dividing, a new set of genes is activated that promote neuronal differentiation. The SoxC transcription factors had previously been implicated in initiating the early stages of neuronal differentiation and were largely considered to act redundantly (Hargrave et al., 1997; Bergsland et al., 2006; Hoser et al., 2008; Bhattaram et al., 2010; Mu et al., 2012). Within the nervous system, however, there are species- and regionspecific characteristics. Therefore, we initiated a series of experiments to inquire into the roles of two SoxC family members, Sox11 and Sox4, in the formation of the mammalian cerebral cortex, arguably the most complex region of any nervous system. The results of these experiments describe unique roles for Sox 11 and Sox 4 in discrete and overlapping populations of cortical neurons and define a new role for Sox 4 in the amplifying divisions of IPCs in the cortical SVZ (Fig. 8).

Sox11 and Sox4 affect neuronal differentiation in all brain regions studied (Hoser et al., 2008; Ling et al., 2009; Mu et al., 2012; Shim et al., 2012). Results presented here extend these findings to the cerebral cortex. In cortical neurogenesis, the general molecular pathways present in other brain regions exist. However, the cortex's large size and complex circuitry is accompanied by additional neuronal heterogeneity during development and in maturity. For example, of the excitatory neurons generated within cortical germinal zones, there is striking variation in gene expression, cell shape, laminar position, synaptic transmission, and neural circuitry (Molyneaux et al., 2007). Although the timing of cell cycle exit corresponds with discrete cortical neuronal populations, the molecular cascades that produce these populations are not always well understood (McConnell, 1985, 1989; Dehay and Kennedy, 2007; Lai et al., 2008; Shim et al., 2012). Our results implicate Sox11 function in defining neurons of the PP, resultant $\mathrm{MZ}$ and SP, and deep $\mathrm{CP}$. Therefore, specific populations of cortical neurons appear to rely on one or both SoxC family members. We suspect that discrete roles in particular pop- 
ulations of cortical neurons reflect both restricted expression of Sox 11 and Sox 4 as well as distinct binding capacities; Sox 11 binds Ngn1 selectively and targets the NeuroD1 gene. Although Sox11 also activates Tubb3, Brn2 antagonizes that action. It is likely that distinct partners may be used in particular populations of neurons, similar to the antagonism between Sox proteins in defining neuronal identity (Shim et al., 2012).

In an unforeseen finding, our data implicate Sox4 in regulating IPC generation in the SVZ, a novel role for a SoxC family member in any developing nervous system. The SVZ has long represented a developmental puzzle. Analyses demonstrate that apical progenitors from the VZ transition into IPCs of the SVZ before giving rise to excitatory neurons of the CP (Miyata et al., 2004; Noctor et al., 2004). It has been proposed that some instruction for neuronal identity may be imbued during this IPC division (Pontious et al., 2008). Interestingly, several recent studies reveal significant cellular complexity within the IPC populations of the SVZ niche (Hansen et al., 2010; Shitamukai et al., 2011; LaMonica et al., 2012; Martínez-Cerdeño et al., 2012; Gertz et al., 2014). Indeed, comparison across species demonstrates that organisms with a larger cerebral cortex tend to have proportionally expanded SVZ size (Martínez-Cerdeño et al., 2012). Moreover, there is increasing recognition of heterogeneity in cell populations in the SVZ as the cortex shifts from the simpler structures found in rodents to the more complex organizations present in primates (Florio and Huttner, 2014).

The involvement of Sox4, a gene that had previously been characterized to act solely in the promotion of neuronal differentiation in other neural systems, in IPC division in the cortical SVZ may be an example of the repurposing of a transcription factor for new function in a more complex brain region. We propose that Sox 4 acts with Ngn2 to activate Tbr2 and initiate IPC specification and then acts with Tbr2 to maintain this basal progenitor state. A prediction of this model is that loss of Sox 4 will result in fewer IPCs, and thus reduced amplification of cortical neurons. Although the cerebral wall of Sox $4{ }^{\mathrm{CKO}}$ mice is thinner at E14.5 compared with controls (data not shown), the thickness of the cerebral wall is no different at P0 (data not shown). It is likely that this dichotomy reflects confounding roles: one in specifying IPCs and another in differentiated neurons. Future experiments will tease out cell-type-specific effects. Nevertheless, given this central role in IPC specification and function, Sox 4 will be an important tool for investigating this still mysterious population of secondary progenitors in the future.

Our results provide support for the intersection of important sets of transcription factors-SoxC, Neurogenins, POU, and Tbox proteins - in adjusting the balance of dividing and differentiating cells during cortical development (Boogerd et al., 2011; Whittington et al., 2015). The Neurogenins present fascinating expression and functional profiles that include both antagonism and collaboration as the nervous system develops (Schuurmans et al., 2004; Dixit et al., 2014; Paul et al., 2014), whereas POU and Tbox genes may be more straightforward in promoting cell fate. (Hevner et al., 2001; Englund et al., 2005; Kolk et al., 2005; Sessa et al., 2010). Sox11 and Sox4 exert specific effects in IPCs and neurons of the SP, MZ, and CP in the early cortex, in apical progenitors and $\mathrm{CP}$ neurons midcorticogenesis, and in all progenitors at birth. These findings provide a new lens with which to view temporally regulated events in the formation of the cerebral cortex and provide a molecular link between cell expansion and neuronal differentiation (Fig. 8).

\section{References}

Altman J, Bayer SA (1990) Vertical compartmentation and cellular transformations in the germinal matrices of the embryonic rat cerebral cortex. Exp Neurol 107:23-35. CrossRef Medline

Anderson SA, Eisenstat DD, Shi L, Rubenstein JL (1997) Interneuron migration from basal forebrain to neocortex: dependence on Dlx genes [see comments]. Science 278:474-476. CrossRef Medline

Arlotta P, Molyneaux BJ, Chen J, Inoue J, Kominami R, Macklis JD (2005) Neuronal subtype-specific genes that control corticospinal motor neuron development in vivo. Neuron 45:207-221. CrossRef Medline

Bergsland M, Werme M, Malewicz M, Perlmann T, Muhr J (2006) The establishment of neuronal properties is controlled by Sox 4 and Sox11. Genes Dev 20:3475-3486. CrossRef Medline

Bergsland M, Ramsköld D, Zaouter C, Klum S, Sandberg R, Muhr J (2011) Sequentially acting Sox transcription factors in neural lineage development. Genes Dev 25:2453-2464. CrossRef Medline

Bernard P, Harley VR (2010) Acquisition of SOX transcription factor specificity through protein-protein interaction, modulation of Wnt signalling and post-translational modification. Int J Biochem Cell Biol 42:400-410. CrossRef Medline

Bhattaram P, Penzo-Méndez A, Sock E, Colmenares C, Kaneko KJ, Vassilev A, Depamphilis ML, Wegner M, Lefebvre V (2010) Organogenesis relies on SoxC transcription factors for the survival of neural and mesenchymal progenitors. Nat Commun 1:9. Medline

Boogerd CJ, Wong LY, van den Boogaard M, Bakker ML, Tessadori F, Bakkers J, 't Hoen PA, Moorman AF, Christoffels VM, Barnett P (2011) Sox4 mediates Tbx3 transcriptional regulation of the gap junction protein Cx43. Cell Mol Life Sci 68:3949-3961. CrossRef Medline

Brazel CY, Romanko MJ, Rothstein RP, Levison SW (2003) Roles of the mammalian subventricular zone in brain development. Prog Neurobiol 69:49-69. CrossRef Medline

Britz O, Mattar P, Nguyen L, Langevin LM, Zimmer C, Alam S, Guillemot F, Schuurmans C (2006) A role for proneural genes in the maturation of cortical progenitor cells. Cereb Cortex 16:i138-i151. CrossRef Medline

Bultje RS, Castaneda-Castellanos DR, Jan LY, Jan YN, Kriegstein AR, Shi SH (2009) Mammalian Par3 regulates progenitor cell asymmetric division via notch signaling in the developing neocortex. Neuron 63:189-202. CrossRef Medline

Cheung M, Abu-Elmagd M, Clevers H, Scotting PJ (2000) Roles of Sox4 in central nervous system development. Brain Res Mol Brain Res 79:180191. CrossRef Medline

Clifford MA, Athar W, Leonard CE, Russo A, Sampognaro PJ, Van der Goes MS, Burton DA, Zhao X, Lalchandani RR, Sahin M, Vicini S, Donoghue MJ (2014) EphA7 signaling guides cortical dendritic development and spine maturation. Proc Natl Acad Sci U S A 111:4994-4999. CrossRef Medline

Costa MR, Bucholz O, Schroeder T, Götz M (2009) Late origin of gliarestricted progenitors in the developing mouse cerebral cortex. Cereb Cortex 19:i135-i143. CrossRef Medline

Dehay C, Kennedy H (2007) Cell-cycle control and cortical development. Nat Rev Neurosci 8:438-450. CrossRef Medline

Dixit R, Wilkinson G, Cancino GI, Shaker T, Adnani L, Li S, Dennis D, Kurrasch D, Chan JA, Olson EC, Kaplan DR, Zimmer C, Schuurmans C (2014) Neurog1 and Neurog2 control two waves of neuronal differentiation in the piriform cortex. J Neurosci 34:539-553. CrossRef Medline

Dy P, Penzo-Méndez A, Wang H, Pedraza CE, Macklin WB, Lefebvre V (2008) The three SoxC proteins-Sox4, Sox11 and Sox12-exhibit overlapping expression patterns and molecular properties. Nucleic Acids Res 36:3101-3117. CrossRef Medline

Englund C, Fink A, Lau C, Pham D, Daza RA, Bulfone A, Kowalczyk T, Hevner RF (2005) Pax6, Tbr2, and Tbr1 are expressed sequentially by radial glia, intermediate progenitor cells, and postmitotic neurons in developing neocortex. J Neurosci 25:247-251. CrossRef Medline

Florio M, Huttner WB (2014) Neural progenitors, neurogenesis and the evolution of the neocortex. Development 141:2182-2194. CrossRef Medline

Ge W, He F, Kim KJ, Blanchi B, Coskun V, Nguyen L, Wu X, Zhao J, Heng JI, Martinowich K, Tao J, Wu H, Castro D, Sobeih MM, Corfas G, Gleeson JG, Greenberg ME, Guillemot F, Sun YE (2006) Coupling of cell migration with neurogenesis by proneural bHLH factors. Proc Natl Acad Sci U S A 103:1319-1324. CrossRef Medline

Gertz CC, Lui JH, LaMonica BE, Wang X, Kriegstein AR (2014) Diverse 
behaviors of outer radial glia in developing ferret and human cortex. J Neurosci 34:2559-2570. CrossRef Medline

Ghysen A, Dambly-Chaudiere C (1989) Genesis of the Drosophila peripheral nervous system. Trends Genet 5:251-255. CrossRef Medline

Goldman JE (1995) Lineage, migration, and fate determination of postnatal subventricular zone cells in the mammalian CNS. J Neurooncol 24:6164. CrossRef Medline

Gorski JA, Talley T, Qiu M, Puelles L, Rubenstein JL, Jones KR (2002) Cortical excitatory neurons and glia, but not GABAergic neurons, are produced in the Emx1-expressing lineage. J Neurosci 22:6309-6314. Medline

Guth SI, Wegner M (2008) Having it both ways: Sox protein function between conservation and innovation. Cell Mol Life Sci 65:3000-3018. CrossRef Medline

Hansen DV, Lui JH, Parker PR, Kriegstein AR (2010) Neurogenic radial glia in the outer subventricular zone of human neocortex. Nature 464:554561. CrossRef Medline

Hargrave M, Wright E, Kun J, Emery J, Cooper L, Koopman P (1997) Expression of the Sox 11 gene in mouse embryos suggests roles in neuronal maturation and epithelio-mesenchymal induction. Dev Dyn 210:79-86. CrossRef Medline

Haydar TF, Wang F, Schwartz ML, Rakic P (2000) Differential modulation of proliferation in the neocortical ventricular and subventricular zones. J Neurosci 20:5764-5774. Medline

Hevner RF, Shi L, Justice N, Hsueh Y, Sheng M, Smiga S, Bulfone A, Goffinet AM, Campagnoni AT, Rubenstein JL (2001) Tbr1 regulates differentiation of the preplate and layer 6. Neuron 29:353-366. CrossRef Medline

Hoser M, Potzner MR, Koch JM, Bösl MR, Wegner M, Sock E (2008) Sox12 deletion in the mouse reveals nonreciprocal redundancy with the related Sox4 and Sox11 transcription factors. Mol Cell Biol 28:4675-4687. CrossRef Medline

Javaherian A, Kriegstein A (2009) A stem cell niche for intermediate progenitor cells of the embryonic cortex. Cereb Cortex 19:i70-i77. CrossRef Medline

Jiang Y, Ding Q, Xie X, Libby RT, Lefebvre V, Gan L (2013) Transcription factors SOX4 and SOX11 function redundantly to regulate the development of mouse retinal ganglion cells. J Biol Chem 288:18429-18438. CrossRef Medline

Kamachi Y, Kondoh H (2013) Sox proteins: regulators of cell fate specification and differentiation. Development 140:4129-4144. CrossRef Medline

Kiefer JC, Jarman A, Johnson J (2005) Pro-neural factors and neurogenesis. Dev Dyn 234:808-813. CrossRef Medline

Kolk SM, Whitman MC, Yun ME, Shete P, Donoghue MJ (2005) A unique subpopulation of Tbr1-expressing deep layer neurons in the developing cerebral cortex. Mol Cell Neurosci 30:538-551. CrossRef Medline

Kovach C, Dixit R, Li S, Mattar P, Wilkinson G, Elsen GE, Kurrasch DM, Hevner RF, Schuurmans C (2013) Neurog2 simultaneously activates and represses alternative gene expression programs in the developing neocortex. Cereb Cortex 23:1884-1900. CrossRef Medline

Kowalczyk T, Pontious A, Englund C, Daza RA, Bedogni F, Hodge R, Attardo A, Bell C, Huttner WB, Hevner RF (2009) Intermediate neuronal progenitors (basal progenitors) produce pyramidal-projection neurons for all layers of cerebral cortex. Cereb Cortex 19:2439-2450. CrossRef Medline

Kriegstein AR (2005) Constructing circuits: neurogenesis and migration in the developing neocortex. Epilepsia 46:15-21. Medline

Kriegstein A, Noctor S, Martínez-Cerdeño V (2006) Patterns of neural stem and progenitor cell division may underlie evolutionary cortical expansion. Nat Rev Neurosci 7:883-890. CrossRef Medline

Lai T, Jabaudon D, Molyneaux BJ, Azim E, Arlotta P, Menezes JR, Macklis JD (2008) SOX5 controls the sequential generation of distinct corticofugal neuron subtypes. Neuron 57:232-247. CrossRef Medline

LaMonica BE, Lui JH, Wang X, Kriegstein AR (2012) OSVZ progenitors in the human cortex: an updated perspective on neurodevelopmental disease. Curr Opin Neurobiol 22:747-753. CrossRef Medline

Lefebvre V, Dumitriu B, Penzo-Méndez A, Han Y, Pallavi B (2007) Control of cell fate and differentiation by Sry-related high-mobility-group box (Sox) transcription factors. Int J Biochem Cell Biol 39:2195-2214. CrossRef Medline

Ling KH, Hewitt CA, Beissbarth T, Hyde L, Banerjee K, Cheah PS, Cannon PZ, Hahn CN, Thomas PQ, Smyth GK, Tan SS, Thomas T, Scott HS
(2009) Molecular networks involved in mouse cerebral corticogenesis and spatio-temporal regulation of Sox4 and Sox11 novel antisense transcripts revealed by transcriptome profiling. Genome Biol 10:R104. CrossRef Medline

Luskin MB (1998) Neuroblasts of the postnatal mammalian forebrain: their phenotype and fate. J Neurobiol 36:221-233. Medline

Ma Q, Fode C, Guillemot F, Anderson DJ (1999) Neurogenin1 and neurogenin2 control two distinct waves of neurogenesis in developing dorsal root ganglia. Genes Dev 13:1717-1728. CrossRef Medline

Martínez-Cerdeño V, Noctor SC, Kriegstein AR (2006) The role of intermediate progenitor cells in the evolutionary expansion of the cerebral cortex. Cereb Cortex 16:i152-i161. CrossRef Medline

Martínez-Cerdeño V, Cunningham CL, Camacho J, Antczak JL, Prakash AN, Cziep ME, Walker AI, Noctor SC (2012) Comparative analysis of the subventricular zone in rat, ferret and macaque: evidence for an outer subventricular zone in rodents. PLoS One 7:e30178. CrossRef Medline

McConnell SK (1985) Migration and differentiation of cerebral cortical neurons after transplantation into the brains of ferrets. Science 229:1268 1271. CrossRef Medline

McConnell SK (1989) The determination of neuronal fate in the cerebral cortex. Trends Neurosci 12:342-349. CrossRef Medline

Miyata T, Kawaguchi A, Saito K, Kawano M, Muto T, Ogawa M (2004) Asymmetric production of surface-dividing and non-surface-dividing cortical progenitor cells. Development 131:3133-3145. CrossRef Medline

Molyneaux BJ, Arlotta P, Menezes JR, Macklis JD (2007) Neuronal subtype specification in the cerebral cortex. Nat Rev Neurosci 8:427-437. CrossRef Medline

Mu L, Berti L, Masserdotti G, Covic M, Michaelidis TM, Doberauer K, Merz K, Rehfeld F, Haslinger A, Wegner M, Sock E, Lefebvre V, CouillardDespres S, Aigner L, Berninger B, Lie DC (2012) SoxC transcription factors are required for neuronal differentiation in adult hippocampal neurogenesis. J Neurosci 32:3067-3080. CrossRef Medline

Noctor SC, Flint AC, Weissman TA, Wong WS, Clinton BK, Kriegstein AR (2002) Dividing precursor cells of the embryonic cortical ventricular zone have morphological and molecular characteristics of radial glia. J Neurosci 22:3161-3173. Medline

Noctor SC, Martínez-Cerdeño V, Ivic L, Kriegstein AR (2004) Cortical neurons arise in symmetric and asymmetric division zones and migrate through specific phases. Nat Neurosci 7:136-144. CrossRef Medline

Noctor SC, Martínez-Cerdeño V, Kriegstein AR (2007a) Neural stem and progenitor cells in cortical development. Novartis Found Symp 2007;288: 59-73; discussion 73-8, 96-8. Medline

Noctor SC, Martínez-Cerdeño V, Kriegstein AR (2007b) Contribution of intermediate progenitor cells to cortical histogenesis. Arch Neurol 64: 639-642. CrossRef Medline

Noctor SC, Martínez-Cerdeño V, Kriegstein AR (2008) Distinct behaviors of neural stem and progenitor cells underlie cortical neurogenesis. J Comp Neurol 508:28-44. CrossRef Medline

North HA, Zhao X, Kolk SM, Clifford MA, Ziskind DM, Donoghue M] (2009) Promotion of proliferation in the developing cerebral cortex by EphA4 forward signaling. Development 136:2467-2476. CrossRef Medline

Ochiai W, Nakatani S, Takahara T, Kainuma M, Masaoka M, Minobe S, Namihira M, Nakashima K, Sakakibara A, Ogawa M, Miyata T (2009) Periventricular notch activation and asymmetric Ngn2 and Tbr2 expression in pair-generated neocortical daughter cells. Mol Cell Neurosci 40: 225-233. CrossRef Medline

Paul V, Tonchev AB, Henningfeld KA, Pavlakis E, Rust B, Pieler T, Stoykova A (2014) Scratch2 modulates neurogenesis and cell migration through antagonism of bHLH proteins in the developing neocortex. Cereb Cortex 24:754-772. CrossRef Medline

Penzo-Méndez A, Dy P, Pallavi B, Lefebvre V (2007) Generation of mice harboring a Sox4 conditional null allele. Genesis 45:776-780. CrossRef Medline

Pontious A, Kowalczyk T, Englund C, Hevner RF (2008) Role of intermediate progenitor cells in cerebral cortex development. Dev Neurosci 30:2432. CrossRef Medline

Potzner MR, Tsarovina K, Binder E, Penzo-Méndez A, Lefebvre V, Rohrer H, Wegner M, Sock E (2010) Sequential requirement of Sox4 and Sox11 during development of the sympathetic nervous system. Development 137:775-784. CrossRef Medline

Qian X, Shen Q, Goderie SK, He W, Capela A, Davis AA, Temple S (2000) 
Timing of CNS cell generation: a programmed sequence of neuron and glial cell production from isolated murine cortical stem cells. Neuron 28:69-80. CrossRef Medline

Rakic P (1972) Mode of cell migration to the superficial layers of fetal monkey neocortex. J Comp Neurol 145:61-83. CrossRef Medline

Scardigli R, Bäumer N, Gruss P, Guillemot F, Le Roux I (2003) Direct and concentration-dependent regulation of the proneural gene Neurogenin2 by Pax6. Development 130:3269-3281. CrossRef Medline

Schilham MW, Oosterwegel MA, Moerer P, Ya J, de Boer PA, van de Wetering M, Verbeek S, Lamers WH, Kruisbeek AM, Cumano A, Clevers H (1996) Defects in cardiac outflow tract formation and pro-B-lymphocyte expansion in mice lacking Sox-4. Nature 380:711-714. CrossRef Medline

Schuurmans C, Armant O, Nieto M, Stenman JM, Britz O, Klenin N, Brown C, Langevin LM, Seibt J, Tang H, Cunningham JM, Dyck R, Walsh C, Campbell K, Polleux F, Guillemot F (2004) Sequential phases of cortical specification involve Neurogenin-dependent and -independent pathways. EMBO J 23:2892-2902. CrossRef Medline

Schwab MH, Druffel-Augustin S, Gass P, Jung M, Klugmann M, Bartholomae A, Rossner MJ, Nave KA (1998) Neuronal basic helix-loop-helix proteins (NEX, neuroD, NDRF): spatiotemporal expression and targeted disruption of the NEX gene in transgenic mice. J Neurosci 18:1408-1418. Medline

Sessa A, Mao CA, Colasante G, Nini A, Klein WH, Broccoli V (2010) Tbr2positive intermediate (basal) neuronal progenitors safeguard cerebral cortex expansion by controlling amplification of pallial glutamatergic neurons and attraction of subpallial GABAergic interneurons. Genes Dev 24:1816-1826. CrossRef Medline

Shim S, Kwan KY, Li M, Lefebvre V, Sestan N (2012) Cis-regulatory control of corticospinal system development and evolution. Nature 486:74-79. Medline

Shitamukai A, Konno D, Matsuzaki F (2011) Oblique radial glial divisions in the developing mouse neocortex induce self-renewing progenitors outside the germinal zone that resemble primate outer subventricular zone progenitors. J Neurosci 31:3683-3695. CrossRef Medline

Sidman RL, Rakic P (1982) Development of the human central nervous system. In: Histology and histopathology of the nervous system (Haymaker W, Adams RD, eds), pp 3-145. Springfield, IL: C.C. Thomas.

Sock E, Rettig SD, Enderich J, Bösl MR, Tamm ER, Wegner M (2004) Gene targeting reveals a widespread role for the high-mobility-group transcription factor Sox11 in tissue remodeling. Mol Cell Biol 24:6635-6644. CrossRef Medline
Takahashi T, Nowakowski RS, Caviness VS Jr (1994) Mode of cell proliferation in the developing mouse neocortex. Proc Natl Acad Sci U S A 91: 375-379. CrossRef Medline

Tarabykin V, Stoykova A, Usman N, Gruss P (2001) Cortical upper layer neurons derive from the subventricular zone as indicated by Svetl gene expression. Development 128:1983-1993. Medline

Thein DC, Thalhammer JM, Hartwig AC, Crenshaw EB 3rd, Lefebvre V, Wegner M, Sock E (2010) The closely related transcription factors Sox4 and Sox11 function as survival factors during spinal cord development. J Neurochem 115:131-141. CrossRef Medline

Tyler WA, Medalla M, Guillamon-Vivancos T, Luebke JI, Haydar TF (2015) Neural precursor lineages specify distinct neocortical pyramidal neuron types. J Neurosci 35:6142-6152. CrossRef Medline

Wang Y, Lin L, Lai H, Parada LF, Lei L (2013) Transcription factor Sox11 is essential for both embryonic and adult neurogenesis. Dev Dyn 242:638653. CrossRef Medline

Whittington N, Cunningham D, Le TK, De Maria D, Silva EM (2015) Sox21 regulates the progression of neuronal differentiation in a dose-dependent manner. Dev Biol 397:237-247. Medline

Wilkinson G, Dennis D, Schuurmans C (2013) Proneural genes in neocortical development. Neuroscience 253:256-273. CrossRef Medline

Wilson M, Koopman P (2002) Matching SOX: partner proteins and cofactors of the SOX family of transcriptional regulators. Curr Opin Genet Dev 12:441-446. CrossRef Medline

Wu SX, Goebbels S, Nakamura K, Nakamura K, Kometani K, Minato N, Kaneko T, Nave KA, Tamamaki N (2005) Pyramidal neurons of upper cortical layers generated by NEX-positive progenitor cells in the subventricular zone. Proc Natl Acad Sci U S A 102:17172-17177. CrossRef Medline

Yoshida M, Suda Y, Matsuo I, Miyamoto N, Takeda N, Kuratani S, Aizawa S (1997) Emx1 and Emx2 functions in development of dorsal telencephalon. Development 124:101-111. Medline

Zecevic N, Chen Y, Filipovic R (2005) Contributions of cortical subventricular zone to the development of the human cerebral cortex. J Comp Neurol 491:109-122. CrossRef Medline

Zimmer C, Tiveron MC, Bodmer R, Cremer H (2004) Dynamics of Cux2 expression suggests that an early pool of SVZ precursors is fated to become upper cortical layer neurons. Cereb Cortex 14:1408-1420. CrossRef Medline 